\title{
THE EFFECTS OF RETIREMENT ON HEALTH-RELATED QUALITY OF LIFE OF RETIREMENT-AGED ADULTS FOR FOUR MARITAL STATUS SUBGROUPS
}

\author{
CHONG-HWAN SON
}

\begin{abstract}
:
Abstract

This study identifies the differences in the effects of retirement on physical/mental health as health-related quality of life (HRQOL) across marital status subgroups for the retirement-aged population from 2005 to 2016. This study conducts a Two-Stage least squares (2SLS) regression analysis using cross-sectional and time series data drawn from the Behavioral Risk Factor Surveillance System (BRFSS). The empirical results suggest that retirement is negatively associated with physical health outcomes, whereas retirement is positively associated with mental health outcomes. Divorced men who are retired are likely to have 2.028 more physically unhealthy days per month than divorced men who are employed. Widowed or never married women who are retired are likely to have 2.208 and 2.203 respectively more physically unhealthy days than widowed or never married women who are employed. These retired females in the marital status subgroups have the worst negative retirement effect on physical health. Divorced respondents who are retired are likely to have 1.478 and 1.129 more mentally unhealthy days per month for males and females respectively than the counterparts of those who are employed. In conclusion, this study finds the existence of disparities in the effects of retirement on HRQOL, such as physical/mental health outcomes by marital status.
\end{abstract}

\section{Keywords:}

Health-Related Quality of Life, Early Retirement Age, Full Retirement Age, BRFSS, Mental Health, Physical Health, Instrument Variables.

JEL Classification: 114, I18, 131

\section{Authors:}

CHONG-HWAN SON, Hudson Valley Community College, United States, Email: c.son@hvcc.edu

\section{Citation:}

CHONG-HWAN SON (2020). The Effects of Retirement on Health-Related Quality of Life of Retirement-Aged Adults for Four Marital Status Subgroups . International Journal of Economic Sciences, Vol. IX(1), pp. 179-201., 10.20472/ES.2020.9.1.010 


\section{Introduction}

As an increase in the average life expectancy over the last decades in the Unites States - the life expectancy at birth for males (females) had increased from 71.8 (78.8) years in 1990 to 76.1 (81.1) years in 2016 (National Centers for Health Statistics, 2017), the elderly population has steadily grown and the proportion of an individual's life in retirement has increased (Horner and Cullen, 2016). It leads to a major public health concern about the potential consequences on health which may affect long-term health care expenditure. As a result, the health issues of the elderly receive more public attention than before. At the same time, the demographic shifts have brought up many questions about the financial sustainability of social security systems, such as Social Security and Medicare. A number of developed countries have raised the pension eligibility age to induce intentionally postponed retirement. In the U.S., policymakers have proposed several health care reforms including a gradual increase in the full retirement age at which retirees receive full benefits from retirement plans including Social Security. It has been increasing in two-month increment each year until reaching 67 years of age in 2025. Raising the full retirement age can cause an increase in the demand for health care and the expenditures associated with it if retirement has a positive association with health. Consequently, expected government financial release from a reduction in the Social Security spending and pension expenditures may not be established due to offsetting by an increase in federal health care spending, such as Medicare and Medicaid services. On the other hand, the increase in the full retirement age may actually reduce health care expenditures if retirement has a negative effect on health (Dave, et al., 2008; Bonsang, et al., 2012). Thus, it is important to perceive the net and causal effects of retirement on health for the total health care expenditure for the elderly.

Retirement is one of the stressful life events: it is accompanied by several basic life changes, such as time availability, income streams, social networks, environmental changes, and so on. The lifestyle changes are likely to affect the retirees' health. However, understanding the net and causal impact of retirement on health would be complicated. First, exiting from working relieves retirees from job-related stress and pressure. In contrast, retirees may face an increase in stress level due to the loss of income and a decline in other social participation. The increase in stress level might lead to a decline in self-respect and social status, isolation, illness, and a decline in happiness and life satisfaction (Halleröd, et al., 2013). Second, earlier retirement such as involuntary retirement due to ill health might be related to poor health. The poor health influences people to retire early, whereas retirement affects the retirees' health. It brings about the possibility of reverse causality in the relationship between retirement and health status. Third, the problem of endogeneity is a major issue in investigating the impact of retirement on health. The endogeneity arises due to the presence of unobserved individual heterogeneity factors, such as generics and time preferences that may affect both the retirement decisions and health. Lastly, there are strong associations between individual preferences with respect to time investment and health status. Time is an important direct input in the production of health capital. The retirees' own time effort can directly affect the level of their health stock. Retired individuals may have more leisure time than when they are in the labor force although it depends on the retired individuals' characteristics because the retirees' opportunity cost of leisure time is lower than the opportunity cost for the individuals in working life. On the other 
hand, retirees may have less incentive to invest in investment commodities for their health to improve working productivity because their earning is no longer health dependent.

Numerous studies within demographic research have consistently identified that married individuals were more likely to report good self-reported health than their unmarried counterparts (Waldron, et al., 1997; Price and Joo, 2005; Shin and Kim, 2017; Jhang, 2018). At the same time, there is increasing diversity in marital status in the U.S. since 1950, such as a decrease in married adults and increases in never married and divorced adults (U.S. Census Bureau, 2018), and there is increasing diversity in marital status at older ages as well due to the increased life expectancy and wealthier, longer, and healthier lives (Robards, et al., 2012; Bookwala, et al., 2014). Retirees may experience better or worse adjustment to the transition of retirement from working based on their marital status. In the context of the social changes at older ages, marital status in retirement-aged adults may be crucial in the transitions that have an impact on their health. Therefore, understanding the relationship between marital status and health at older ages becomes of increasing importance, and the effects of retirement on health outcomes by marital status should be extensively highlighted. However, a few previous investigations have brought attention to how marital status plays a role in the effects of retirement on health outcomes. To evaluate whether the effects of retirement on health differ by marital status, the goal of this paper is to identify the differences in the effects of retirement on physical/mental health as health-related quality of life (HRQOL) across marital status subgroups (married, divorced, never married, and widowed) for the retirement-aged adults (55-74 years of age) for all 50 states and Washington D.C. from 2005 to 2016 in the U.S. The retirement ages as 55-74 years of age is defined by the study (Kuvaja-Köllner, et al., 2013), but the retirement ages have been widely defined from 45 to 79 years of age in the earlier studies (Bonsang, et al., 2012; Eibich, 2015; Vo, et al., 2015; Hessel, 2016; Zhu, 2016). The period from 2005 to 2016 is meaningful for the social security retirement benefits - both the early retirement age of 62 and the full retirement age of 66 had remained unchanged only during the period in the U.S.

This study conducts a Two-Stage least squares (2SLS) regression analysis to try to remove the bias due to unobserved heterogeneity, endogeneity, and potential reverse causality (details in section 2) using cross-sectional and time series data drawn from the Behavioral Risk Factor Surveillance System (BRFSS). The BRFSS is a large-scale national health survey, a collaborative project between the Centers for Disease Control and Prevention (CDC) and all of the states in the United States. The BRFSS is designed to conduct monthly ongoing healthrelated telephone surveys to collect uniform state-specific data on health-related risk behaviors, chronic diseases and health conditions, access to health care, and use of preventive services related to the leading causes of death and disability from the non-institutionalized adult population aged 18 years or older residing in the United States. The detail of the BRFSS data is presented in section 3 .

\section{Analytical Framework}

The basic framework of theoretical development for investigating the effects of retirement on health outcomes can be within the human capital model of the demand for health (Grossman, 
1972). The model presented that consumers purchased medical care or medical services for good health. It logically assumed that the demand for medical care or medical services established the model of the demand for health itself. Retirees' the demand for health capital can be approached with consumption and investment aspects. First, a consumption commodity of the demand for health enters the utility function. Retirees may increase the production of the commodities in order to reduce the time loss from daily activities and to enjoy healthy days to raise the level of utility: unhealthy days are a source of disutility. In this case, the retirees' health would be expected to be improved. On the other hand, the investment aspect of demand for health refers to that an individual's good health raises her/his earnings due to reducing the number of unproductive days when the individual is in the labor force. Thus, the working individuals would care for their health in order to sustain or increase working productivity before retirement. However, retirees have less incentive to invest in investment commodities for their health to improve working productivity because their earning is no longer health dependent. From this investment aspect of the demand for health, retirement could lead to a reduction in the investment for health capital and to a decline in retirees' health stock in the long-run. Thus, the net effect of retirement on health for retirees becomes ambiguous.

In addition, if the rate of depreciation on the physical stock of health rises with aging after a certain age, the full price of the investment in health capital for improving or sustaining the same level of the health stock increases as age rises. According to the law of demand, the quantity of health demanded is inversely related to its full price, ceteris paribus. As a result, the increase in the full price of the investment in health capital causes a decrease in the demand for health inputs, such as the quantity of medical services demanded. On the other hand, retirees raise the quantity of health inputs demanded such as time because of a decrease in the full price of health investment due to reduction in retirees' opportunity cost of time although the money price of health inputs is unchanged: the monetary value of time for retirees is less than the monetary value of time when they are in the labor force. Thus, it is theoretically not possible to make a clear prediction with respect to the impact of retirement on health, and this becomes primarily an empirical issue (Latif, 2012).

HRQOL, a measure of health outcomes, is widely defined as not just the absence of disease but the presence of a positive state of physical, mental, social and spiritual well-being (Son, 2018). The conceptual boundaries of the HRQOL go above the conflict of the health-disease process and additional aspects that contribute to health. As HRQOL is the dependent variable, the model of health outcomes is following (Son, 2016; Son, 2018):

$$
\mathrm{H}=f(\mathrm{~d}, \mathrm{z})
$$

where ' $\mathrm{H}$ ' denotes a measure of health outcomes, the number of physically/mentally unhealthy days in the past 30 days. The number of unhealthy days as a continuous variable ranges from 0 to 30 days (Jia and Lubetkin, 2009; Clifford et al., 2013; Mahabaleshwarkar et al., 2013; Son, 2016; Son, 2018). 'd' represents a group of socio-demographic variables (retirement status, age, educational level, and income level, and race/ethnicity), selected health behavior variables (exercise, smoking status, and drinking status), and chronic health conditions (CVD HA, CVD 
CHD, CVD stroke, asthma, and diabetes). ' $z$ ' is a vector of all other relevant factors of health outcomes. The econometric specification for the health production function is the following:

$$
H_{i j t}=\beta_{0}+r_{i j t} \beta_{r}+x_{i j t k} \beta_{k}+s_{j} \delta_{j}+t_{t} \delta_{t}+u_{i j t}
$$

where subscript $i$ denotes an individual observation. $H_{i j t}$ represents the number of physically/mentally unhealthy days of individual $i$ in state $j$ at interview year $t, r_{i j t}$ is a binary variable indicating the retirement status of individual $i$ in state $j$ at interview year $t ; x_{\text {ijtk }}$ is a vector of personal characteristics including demographic variables, health behavioral variables, and chronic health conditions, where $\mathrm{k}$ represents the number of explanatory variables; $\mathrm{s}_{\mathrm{j}}$ is a state fixed-effect; and $t_{t}$ represents the interview year. $\beta_{0}$ is a fixed non-random constant; $\beta_{r}$ is the coefficient of retirement status; $\beta_{k}$ is a coefficient matrix of the personal characteristics with a dimension $\mathrm{k} \times 1 ; \delta_{j}$ is a coefficient of the individual state $j ; \delta_{t}$ is a coefficient of the interview year $t$, and $u_{\mathrm{ijt}}$ is an error term of the ith observation in state $j$ at year $t$, an independent random variable with mean zero and constant standard error $\sigma_{\mathrm{u}}$. It is generally assumed that Cov $\left(\mathrm{r}_{\mathrm{ijt}}, \mathrm{u}_{\mathrm{ijt}}\right)$ $=0$ and $\operatorname{Cov}\left(x_{i j t k}, u_{i j t}\right)=0$ (Mesbah, 2004; Jia and Lubetkin, 2009; Son and Lee, 2014) with expected value of $u_{i j t}, E\left(u_{i j t}\right)=0$.

Under the classical assumption of Ordinary Least Squares (OLS) estimation, if retirement status $\left(r_{i j t}\right)$ is correlated with the error term $\left(u_{i j t}\right)$ due to endogeneity, in which case the OLS estimator of $\beta_{r}$ is inconsistent. Actually, there is a good reason to believe that the retirement status $\left(r_{i j t}\right)$ is endogenous in equation (2). At first, omitted variables, such as unobserved individual heterogeneities (genetics, life history, food preferences over the life-course, time preference, or unobservable health status) could have an impact on both retirement and health outcomes. The econometric concern, however, is whether health status is a crucial determinant in the decision to retire. Earlier retirement such as involuntary retirement because of ill health might be related to poor health (Vo, et al., 2015). It brings about the possibility of reverse causality in the relationship between retirement and health status in equation (2): the poor health influences people to retire early, whereas retirement affects the retirees' health. Also, previous studies (Zhu, 2016; Motegi, et al., 2016) reported that better health status had a positive and significant impact on both labor force participation and the number of hours worked: health was a key determinant of an individual's labor force participation and retirement behavior. As a result, the estimates of the effects of retirement on health are likely to be biased upward: overestimating the negative effects of retirement on health. Thus, the OLS regression coefficient $\left(\beta_{r}\right)$ from equation (2) is likely to be inconsistent.

To address the endogeneity problem and the potential reverse causality, this study employs the method of Instrumental Variable (IV) estimation which has been well proven in the literature for using the data as similar to the data this paper dealing with. Previous studies (Dave, et al., 2008; Latif, 2012; Kuvaja-Köllner, et al., 2013; Eibich, 2015; Zhu, 2016; Godard, 2016; Hessel, 2016; Motegi, et al., 2016) suggested that the estimation would be restricted to that retirement was the only channel through which individual health outcomes could be affected by the instrumental variables. A good instrument should be strongly correlated with actual retirement behavior, but it should not directly affect health outcomes. The large increases in the retirement decision at 
ages 62 and 66 have been well noted in the literature. Age 62 is the earliest age at which social security benefits can be claimed and where the financial incentives to retire are the strongest, whereas age 66 represents the full retirement age at which individuals can receive full social security benefits if they retire that age. The financial incentives induced by the social security receipt have been found to play a significant role in a large spike in the probability of being retired at these ages (see descriptive statistical analysis of data in current study in section 4). Thus, this paper employs the IV estimation using the early and full retirement ages as identifying instruments for the retirement decision (Bonsang, et al., 2012; Eibich, 2015; Godard, 2016; Zhu, 2016).

The IV estimation consists of two stages. In the first stage, this study estimates the retirement probability by the following equation with time series data:

$$
r_{i j t}=\alpha_{0}+E A_{i j t} \alpha_{e r a}+\mathrm{FRA}_{\mathrm{ijt}} \alpha_{f r a}+\mathrm{x}_{\mathrm{ijtk}} \alpha_{k}+\mathrm{s}_{\mathrm{j}} \lambda_{j}+\mathrm{t}_{\mathrm{t}} \lambda_{t}+\mathrm{e}_{\mathrm{ijt}}
$$

where $E R A_{i j t}$ and $F R A_{i j t}$ are the instruments for the retirement status $\left(r_{i j t}\right)$. $E R A_{i j t}$ equals 1 if an individual reaches the early retirement age (62), and FRA $A_{i j t}$ equals 1 if an individual reaches the full retirement age (66). $\alpha_{\text {era }}$ is a coefficient of early retirement age; $\alpha_{\text {fra }}$ is a coefficient of full retirement age; $\mathrm{a}_{k}$ is a coefficient matrix with a dimension $\mathrm{k} \times 1 ; \lambda_{j}$ is a coefficient of individual state $j$; and $\lambda_{\mathrm{t}}$ is a coefficient of interview year $t$. This study substitutes the predicted value of retirement status $\left(r_{i j t}\right)$ from equation (3) for the retirement status $\left(r_{i j t}\right)$ in equation (2), and then the empirical model becomes the following:

$$
\mathrm{H}_{\mathrm{ijt}}=\beta_{0}+\left(\text { predicted } \mathrm{r}_{\mathrm{ijt}}\right) \beta r+\mathrm{x}_{\mathrm{ijt} k} \beta_{k}+\mathrm{s}_{\mathrm{j}} \delta_{j}+\mathrm{t}_{\mathrm{t}} \delta_{t}+\mathrm{u}_{\mathrm{ijt}}
$$

The predicted $r_{i j t}$ is exogenous to all observed and unobserved individual-level characteristics in equation (4). This state-fixed effect model holds constant differences that are time-invariant across states, removes the effects of differences associated with other relevant independent variables among states on the dependent variables, and captures the effects of unobserved state-specific variables. For example, residents in higher and lower income states may have different profiles of risk factors for health outcomes because people who live in lower income states are likely to exhibit a lower level of demand for medical and healthcare services than people who live in higher income states. The year dummy variable holds constant determinants of HRQOL that vary uniformly across states over time, such as widely dispersed changes in medical practices.

The following equation (5) is a probability of retiring for individual $i$ to provide the result of Figure 2. This equation is derived by substituting the self-reported ages for all age variables (age, early retirement age, and full retirement age) in equation (3)

$$
r_{i j t}=\alpha_{0}+A_{g e} \alpha_{a}+x_{i j t k} \alpha_{k}+s_{j} \lambda_{j}+t_{t} \lambda_{t}+e_{i j t}
$$

where Age $_{\mathrm{i}}$ is the age of individual $l ; \alpha_{a}$ is the coefficient of age. 


\section{EMPIRICAL IMPLEMENTATION}

The data for the present study are drawn from the BRFSS which is a large-scale national health survey, a collaborative project between the CDC and all of the states in the United States. The BRFSS is designed to conduct monthly ongoing health-related telephone surveys to collect uniform state-specific data on health-related risk behaviors, chronic diseases and health conditions, access to health care, and use of preventive services related to the leading causes of death and disability from the non-institutionalized adult population aged 18 years or older residing in the United States. The BRFSS operations are managed by state health departments that follow the guidelines provided by the states with technical assistance provided by the CDC. Some states from the beginning stratified population allow them to collect region-wise data in their own states. The BRFSS questionnaire consists of three parts: a core component as a standard set of questions asked by all states, optional CDC modules supported by the CDC as questions on specific topics that states elect to use on their questionnaires, and state-added questions as questions developed or acquired by participating states which are added to their questionnaires. The state health department and the CDC agree on the content of the core component and optional modules each year. The BRFSS guidelines specify that all states ask the core component questions without modification, but states may choose to add any, all, or none of the optional modules.

The total baseline observations for adults aged $55-74$ years for all 50 states and Washington D.C. from 2005 to 2016 are 2,065,422. Excluding observations that have missing values, unanswered questions, don't know/not sure, questions not asked, and refusals, 1,318,704 survey participants $(63.85 \%$ of the total baseline observations) complete all questions pertaining to perceived numbers of physically/mentally unhealthy days, socio-demographic variables, health behavior variables, and chronic health conditions. The observations are further subdivided into eight gender- and marital-specific subgroups. Descriptions and summary statistics are shown in Tables 1 and 2.

\subsection{Health-related Quality of Life and marital status}

The survey participants are asked about the number of days during the preceding 30 days when physical health which includes physical illness and injury is not good and when mental health which includes stress, depression, and problems with emotion is not good. Physical health status is asked using the question: "Now thinking about your physical health, which includes physical illness and injury, for how many days during the past 30 days was your physical health not good?" Mental health status is asked using the question: "Now thinking about your mental health, which includes stress, depression, and problems with emotions, for how many days during the past 30 days was your mental health not good?" The number of physically/mentally unhealthy days is served as a measure of HRQOL. The number of unhealthy days ranges from 0 to 30 days with a logical maximum of 30 unhealthy days per month. The measure of HRQOL from the BRFSS has been tested and established for their validity and reliability in the previous studies (Anderson, et al., 2003; Brown, et al., 2004; Evenson and McGinn, 2005; Kapp, et al., 2009) and has been widely used in public health studies. 
Table 1: Definition, mean, and standard deviations of variables ${ }^{a}$

\begin{tabular}{|c|c|c|}
\hline Variable & Definition & Mean (SD) \\
\hline PhysHLTH & Number of days when physical health was not good during the past 30 days. & $3.502(7.931)$ \\
\hline MentHLTH & Number of days when mental health was not good during the past 30 days. & $2.231(6.272)$ \\
\hline Retired & Dichotomous variable that equals 1 if respondent is retired. & $0.457(0.498)$ \\
\hline Age & Respondent's reported age in years. & $63.278(5.534)$ \\
\hline Early Ret. age & Dichotomous variable that equals 1 if respondent's age $>62$. & $0.577(0.494)$ \\
\hline Full Ret. age & Dichotomous variable that equals 1 if respondent's age $>66$. & $0.353(0.478)$ \\
\hline Health care & $\begin{array}{l}\text { Dichotomous variable that equals } 1 \text { if respondent has any kind of health care coverage, } \\
\text { including health insurance, prepaid plans such as HMOs, or government plans such as } \\
\text { Medicare, or Indian Health Service. }\end{array}$ & $0.941(0.235)$ \\
\hline \multicolumn{3}{|c|}{ 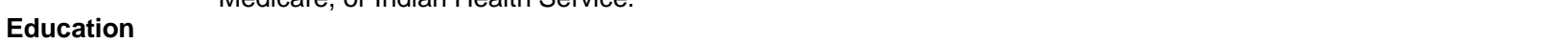 } \\
\hline Less HS & Dichotomous variable that equals 1 if respondent did not graduate high school. & $0.081(0.273)$ \\
\hline HS & Dichotomous variable that equals 1 if respondent graduated high school. & $0.273(0.446)$ \\
\hline Some College & Dichotomous variable that equals 1 if respondent attended college or technical school. & $0.291(0.454)$ \\
\hline College Grad. & $\begin{array}{l}\text { Dichotomous variable that equals } 1 \text { if respondent graduated from college (college } 4 \text { years or } \\
\text { more). }\end{array}$ & $0.355(0.479)$ \\
\hline \multicolumn{3}{|c|}{ 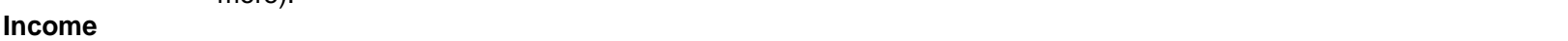 } \\
\hline Income \$20 & Dichotomous variable that equals 1 if respondent's annual household income $<\$ 20,000$. & $0.113(0.317)$ \\
\hline $\begin{array}{l}\text { Income } \$ 20 \text { - } \\
35\end{array}$ & $\begin{array}{l}\text { Dichotomous variable that equals } 1 \text { if } \$ 20,000 \leq \text { respondent's annual household income }< \\
\$ 35,000 \text {. }\end{array}$ & $0.197(0.398)$ \\
\hline $\begin{array}{l}\text { Income } \$ 35- \\
50\end{array}$ & $\begin{array}{l}\text { Dichotomous variable that equals } 1 \text { if } \$ 35,000 \leq \text { respondent's annual household income }< \\
\$ 50,000 \text {. }\end{array}$ & $0.168(0.374)$ \\
\hline $\begin{array}{l}\text { Income } \$ 50- \\
75\end{array}$ & $\begin{array}{l}\text { Dichotomous variable that equals } 1 \text { if } \$ 50,000 \leq \text { respondent's annual household income }< \\
\$ 75,000 \text {. }\end{array}$ & $0.190(0.392)$ \\
\hline $\begin{array}{l}\text { Income } \$ 75+ \\
\text { Race }\end{array}$ & Dichotomous variable that equals 1 if respondent's annual household income $\geq \$ 75,000$. & $0.332(0.471)$ \\
\hline White & Dichotomous variable that equals 1 if respondent is White, but not Hispanic. & $0.786(0.410)$ \\
\hline Black & Dichotomous variable that equals 1 if respondent is Black, but not Hispanic. & $0.087(0.282)$ \\
\hline Hispanic & Dichotomous variable that equals 1 if respondent is Hispanic. & $0.073(0.260)$ \\
\hline \multirow{2}{*}{\multicolumn{3}{|c|}{ Health behavior }} \\
\hline & & \\
\hline Exercise & $\begin{array}{l}\text { Dichotomous variable that equals } 1 \text { if respondent participates in any physical activities or } \\
\text { exercises such as running, calisthenics, golf, gardening, or walking for exercise during the past } \\
\text { month. }\end{array}$ & $0.760(0.427)$ \\
\hline $\begin{array}{l}\text { Current } \\
\text { smoker }\end{array}$ & $\begin{array}{l}\text { Dichotomous variable that equals } 1 \text { if respondent now smokes cigarettes every day or some } \\
\text { days. }\end{array}$ & $0.133(0.339)$ \\
\hline $\begin{array}{l}\text { Current } \\
\text { drinker }\end{array}$ & $\begin{array}{l}\text { Dichotomous variable that equals } 1 \text { if respondent had at least one drink of alcohol in the past } 30 \\
\text { days }{ }^{b} \text {. }\end{array}$ & $0.540(0.498)$ \\
\hline \multicolumn{3}{|c|}{ Chronic health conditions } \\
\hline CVD HA & $\begin{array}{l}\text { Dichotomous variable that equals } 1 \text { if respondent has ever had a heart attack, also called a } \\
\text { myocardial infarction. }\end{array}$ & $0.069(0.253)$ \\
\hline CVD CHD & $\begin{array}{l}\text { Dichotomous variable that equals } 1 \text { if respondent has ever had angina or coronary heart } \\
\text { disease. }\end{array}$ & $0.077(0.267)$ \\
\hline CVD stroke & Dichotomous variable that equals 1 if respondent has ever had a stroke. & $0.037(0.188)$ \\
\hline Asthma & Dichotomous variable that equals 1 if respondent has ever had asthma. & $0.110(0.313)$ \\
\hline Diabetes & Dichotomous variable that equals 1 if respondent has ever had diabetes. & $0.168(0.374)$ \\
\hline
\end{tabular}

Earlier studies (Ford, et al., 2008; Heath and Brown, 2009; Chen, et al., 2011; Mahabaleshwarkar, et al., 2013; Gandhi, et al., 2015) constructed the number of unhealthy days into mutually exclusive categories using 14 days or more as a cutoff point for determining the chronic presence of physical or mental health problems. Using any cut-off value or the threshold of 14 days or more for the unhealthy days can be problematic. Hypothetically, a survey participant who reports zero unhealthy days during the past 30 days is indifferent from a participant who reports 13 unhealthy days in the empirical analysis if a study sets a cutoff value. Because of this solicitude, this study accounts the number of unhealthy days as a continuous variable (Jia and Lubetkin, 2009; Zullig and Hendryx, 2010; Horner-Johnson, et al., 2010; Son 
Table 2: Summary statistics

\begin{tabular}{|c|c|c|c|c|c|c|c|c|c|c|}
\hline \multirow{3}{*}{ Proportion } & \multicolumn{2}{|c|}{ Overall } & \multicolumn{2}{|c|}{ Married } & \multicolumn{2}{|c|}{ Divorced } & \multicolumn{2}{|c|}{ Widowed } & \multicolumn{2}{|c|}{ Never Married } \\
\hline & \multicolumn{2}{|c|}{1.0000} & \multicolumn{2}{|c|}{0.698} & \multicolumn{2}{|c|}{0.156} & \multicolumn{2}{|c|}{0.092} & \multicolumn{2}{|c|}{0.054} \\
\hline & Male & Female & Male & Female & Male & Female & Male & Female & Male & Female \\
\hline \multirow[t]{2}{*}{ PhysHLTH } & 3.325 & 3.697 & 3.094 & 3.251 & 4.242 & 4.346 & 4.352 & 4.593 & 3.700 & 4.014 \\
\hline & $(7.878)$ & $(7.985)$ & (7.573) & (7.423) & $(8.948)$ & $(8.697)$ & (9.091) & (8.974) & $(8.232)$ & $(8.262)$ \\
\hline \multirow[t]{2}{*}{ MentHLTH } & 1.771 & 2.737 & 1.525 & 2.374 & 2.646 & 3.451 & 2.965 & 3.239 & 2.326 & 2.970 \\
\hline & $(5.717)$ & (6.794) & $(5.256)$ & $(6.256)$ & (7.071) & (7.649) & (7.582) & $(7.555)$ & $(6.437)$ & $(6.977)$ \\
\hline \multirow[t]{2}{*}{ Retired } & 0.448 & 0.468 & 0.436 & 0.454 & 0.454 & 0.392 & 0.658 & 0.642 & 0.434 & 0.415 \\
\hline & $(0.497)$ & $(0.499)$ & $(0.496)$ & $(0.498)$ & $(0.498)$ & $(0.488)$ & $(0.474)$ & $(0.480)$ & $(0.496)$ & $(0.493)$ \\
\hline Age & 63.245 & 63.313 & 63.229 & 62.729 & 62.817 & 63.017 & 66.383 & 66.524 & 61.961 & 62.252 \\
\hline & $(5.522)$ & $(5.547)$ & $(5.508)$ & $(5.393)$ & (5.379) & (5.407) & $(5.405)$ & (5.311) & (5.248) & $(5.370)$ \\
\hline Early Ret. age & 0.575 & 0.579 & 0.573 & 0.539 & 0.553 & 0.564 & 0.782 & 0.799 & 0.476 & 0.492 \\
\hline & $(0.494)$ & $(0.494)$ & $(0.495)$ & $(0.498)$ & $(0.497)$ & $(0.496)$ & $(0.413)$ & $(0.401)$ & (0.499) & $(0.500)$ \\
\hline Full Ret. age & 0.349 & 0.357 & 0.347 & 0.313 & 0.318 & 0.334 & 0.590 & 0.601 & 0.256 & 0.281 \\
\hline & $(0.477)$ & $(0.479)$ & $(0.476)$ & $(0.464)$ & $(0.466)$ & $(0.472)$ & $(0.492)$ & $(0.490)$ & $(0.437)$ & $(0.450)$ \\
\hline Health care & 0.938 & 0.946 & 0.951 & 0.958 & 0.880 & 0.913 & 0.936 & 0.948 & 0.883 & 0.922 \\
\hline & $(0.242)$ & $(0.227)$ & $(0.217)$ & $(0.201)$ & $(0.325)$ & $(0.283)$ & $(0.244)$ & $(0.222)$ & $(0.321)$ & $(0.269)$ \\
\hline Less HS & 0.091 & 0.070 & 0.083 & 0.054 & 0.122 & 0.077 & 0.157 & 0.124 & 0.083 & 0.073 \\
\hline & $(0.288)$ & $(0.255)$ & $(0.276)$ & $(0.226)$ & $(0.327)$ & $(0.267)$ & (0.364) & $(0.330)$ & $(0.276)$ & $(0.261)$ \\
\hline HS & 0.258 & 0.290 & 0.248 & 0.285 & 0.289 & 0.274 & 0.325 & 0.360 & 0.264 & 0.216 \\
\hline & $(0.437)$ & $(0.454)$ & $(0.432)$ & $(0.451)$ & $(0.454)$ & $(0.446)$ & $(0.469)$ & $(0.480)$ & $(0.441)$ & $(0.412)$ \\
\hline Some College & 0.271 & 0.313 & 0.266 & 0.311 & 0.305 & 0.340 & 0.270 & 0.305 & 0.268 & 0.267 \\
\hline & $(0.445)$ & $(0.464)$ & $(0.442)$ & $(0.463)$ & $(0.462)$ & $(0.474)$ & $(0.444)$ & $(0.460)$ & $(0.443)$ & $(0.443)$ \\
\hline College Grad. & 0.380 & 0.327 & 0.403 & 0.350 & 0.283 & 0.309 & 0.248 & 0.211 & 0.385 & 0.443 \\
\hline & $(0.486)$ & $(0.469)$ & $(0.491)$ & $(0.477)$ & $(0.451)$ & $(0.462)$ & $(0.432)$ & $(0.408)$ & $(0.487)$ & $(0.497)$ \\
\hline Income $\$ 20$ & 0.093 & 0.135 & 0.059 & 0.059 & 0.210 & 0.241 & 0.209 & 0.287 & 0.230 & 0.209 \\
\hline & $(0.291)$ & $(0.342)$ & $(0.235)$ & $(0.235)$ & (0.407) & $(0.428)$ & $(0.407)$ & $(0.452)$ & $(0.421)$ & $(0.407)$ \\
\hline Income $\$ 20-35$ & 0.178 & 0.219 & 0.151 & 0.163 & 0.266 & 0.286 & 0.304 & 0.352 & 0.264 & 0.257 \\
\hline & $(0.382)$ & $(0.414)$ & $(0.358)$ & $(0.369)$ & $(0.442)$ & $(0.452)$ & $(0.460)$ & $(0.478)$ & $(0.441)$ & $(0.437)$ \\
\hline Income $\$ 35-50$ & 0.163 & 0.174 & 0.157 & 0.172 & 0.180 & 0.184 & 0.189 & 0163 & 0.182 & 0.195 \\
\hline & $(0.369)$ & $(0.379)$ & $(0.364)$ & $(0.377)$ & $(0.384)$ & $(0.388)$ & $(0.391)$ & $(0.369)$ & $(0.386)$ & $(0.396)$ \\
\hline Income $\$ 50-75$ & 0.191 & 0.187 & 0.201 & 0.216 & 0.160 & 0.159 & 0.148 & 0.110 & 0.158 & 0.179 \\
\hline & $(0.393)$ & $(0.390)$ & $(0.401)$ & $(0.411)$ & $(0.367)$ & $(0.366)$ & $(0.355)$ & $(0.312)$ & $(0.365)$ & $(0.383)$ \\
\hline Income $\$ 75+$ & 0.375 & 0.285 & 0.432 & 0.391 & 0.184 & 0.130 & 0.151 & 0.089 & 0.166 & 0.160 \\
\hline & $(0.484)$ & $(0.451)$ & $(0.495)$ & $(0.488)$ & $(0.388)$ & $(0.336)$ & $(0.358)$ & $(0.284)$ & $(0.372)$ & $(0.367)$ \\
\hline White & 0.785 & 0.787 & 0.800 & 0.831 & 0.721 & 0.715 & 0.754 & 0.751 & 0.750 & 0.640 \\
\hline & $(0.411)$ & $(0.410)$ & $(0.400)$ & $(0.375)$ & (0.449) & $(0.452)$ & $(0.430)$ & $(0.433)$ & $(0.433)$ & $(0.480)$ \\
\hline Black & 0.079 & 0.097 & 0.063 & 0.060 & 0.137 & 0.153 & 0.119 & 0.132 & 0.133 & 0.216 \\
\hline & $(0.269)$ & $(0.296)$ & $(0.243)$ & $(0.238)$ & $(0.344)$ & $(0.360)$ & $(0.324)$ & (0.339) & (0.339) & $(0.411)$ \\
\hline Hispanic & 0.079 & 0.066 & 0.078 & 0.058 & 0.091 & 0.083 & 0.076 & 0.070 & 0.066 & 0.082 \\
\hline & $(0.269)$ & $(0.248)$ & $(0.268)$ & $(0.234)$ & $(0.287)$ & $(0.275)$ & $(0.266)$ & $(0.255)$ & $(0.248)$ & $(0.274)$ \\
\hline Other race & 0.058 & 0.051 & 0.059 & 0.051 & 0.052 & 0.050 & 0.051 & 0.047 & 0.052 & 0.062 \\
\hline & $(0.233)$ & (0.219) & $(0.236)$ & $(0.219)$ & $(0.221)$ & $(0.217)$ & $(0.219)$ & $(0.212)$ & $(0.222)$ & $(0.241)$ \\
\hline Exercise & 0.773 & 0.747 & 0.786 & 0.773 & 0.730 & 0.716 & 0.704 & 0.689 & 0.744 & 0.717 \\
\hline & $(0.419)$ & $(0.435)$ & $(0.410)$ & $(0.419)$ & $(0.444)$ & $(0.451)$ & $(0.457)$ & $(0.463)$ & $(0.437)$ & $(0.451)$ \\
\hline Current smoker & 0.141 & 0.124 & 0.115 & 0.095 & 0.248 & 0.183 & 0.229 & 0.168 & 0.185 & 0.134 \\
\hline & $(0.348)$ & $(0.330)$ & $(0.319)$ & $(0.293)$ & $(0.432)$ & $(0.387)$ & $(0.420)$ & $(0.374)$ & $(0.389)$ & $(0.340)$ \\
\hline Current drinker & 0.594 & 0.481 & 0.603 & 0.515 & 0.581 & 0.464 & 0.534 & 0.382 & 0.532 & 0.433 \\
\hline & $(0.491)$ & $(0.500)$ & $(0.489)$ & $(0.500)$ & $(0.493)$ & $(0.499)$ & (0.499) & $(0.486)$ & $(0.499)$ & $(0.495)$ \\
\hline CVD HA & 0.096 & 0.038 & 0.094 & 0.031 & 0.107 & 0.045 & 0.141 & 0.064 & 0.068 & 0.035 \\
\hline & $(0.295)$ & $(0.192)$ & $(0.292)$ & $(0.172)$ & $(0.309)$ & $(0.206)$ & $(0.348)$ & $(0.244)$ & $(0.252)$ & $(0.184)$ \\
\hline CVD CHD & 0.103 & 0.048 & 0.105 & 0.041 & 0.098 & 0.054 & 0.125 & 0.074 & 0.075 & 0.040 \\
\hline & $(0.304)$ & $(0.214)$ & $(0.306)$ & $(0.199)$ & $(0.298)$ & $(0.225)$ & $(0.331)$ & $(0.262)$ & $(0.263)$ & $(0.195)$ \\
\hline CVD stroke & 0.039 & 0.034 & 0.036 & 0.027 & 0.052 & 0.040 & 0.064 & 0.055 & 0.036 & 0.031 \\
\hline & $(0.195)$ & $(0.181)$ & $(0.187)$ & $(0.163)$ & $(0.221)$ & (0.197) & $(0.245)$ & $(0.228)$ & $(0.185)$ & $(0.173)$ \\
\hline Asthma & 0.087 & 0.134 & 0.086 & 0.127 & 0.095 & 0.151 & 0.089 & 0.138 & 0.092 & 0.152 \\
\hline & $(0.282)$ & $(0.341)$ & $(0.280)$ & $(0.333)$ & $(0.293)$ & $(0.358)$ & $(0.285)$ & $(0.345)$ & $(0.289)$ & (0.359) \\
\hline Diabetes & 0.183 & 0.151 & 0.181 & 0.131 & 0.184 & 0.161 & 0.226 & 0.202 & 0.177 & 0.188 \\
\hline & $(0.387)$ & $(0.358)$ & $(0.385)$ & $(0.338)$ & $(0.388)$ & $(0.368)$ & $(0.418)$ & $(0.402)$ & $(0.382)$ & $(0.390)$ \\
\hline
\end{tabular}

Notes: Standard deviations (S.D.) are in parentheses. Means and Standard Deviations are weighted by the BRFSS sample weight factor. All means are statistically significant using two tailed t-test with $95 \%$ confidence interval.

Source: Own calculations based on the 2005-2016 BRFSS data. 
2018). Thus, participants report the more unhealthy days during the past month as poorer HRQOL. The average numbers of physically and mentally unhealthy days per month are 3.502 and 2.231 days respectively (Table 1 ).

Respondents are asked about six categories of marital status: married, divorced, widowed, separated, never married, and a member of an unmarried couple. They are then classified into four marital subgroups: married (married or a member of an unmarried couple), divorced (divorced or separated), widowed, and never married. After regrouping, 811,343 (69.80\%), 250,735 (15.60\%), 171,217 (9.20\%), and 85,409 (5.4\%) of survey participants are married, divorced, widowed, and never married respectively (Table 2).

\subsection{Explanatory Variables}

First, socio-demographic variables are age, retirement status, education level, income level, and race/ethnicity. Second, health behavioral variables are current exercise, current smoker, and current drinker. These demographic and health behavior variables are widely used in public health studies (Meyer, et al., 2014; Hessel, 2016; Horner and Cullen, 2016; Zhu, 2016; Shai, 2018). Third, chronic health conditions are heart attack, coronary heart disease, stroke, asthma, and diabetes. The descriptions, means, and standard deviations are shown in Tables 1 and 2 . Besides these variables, health care access availability is in the empirical models. The health care access availability is obtained from the question: "Do you have any kind of health care coverage, including health insurance, prepaid plans such as HMOs, or government plans such as Medicare, or Indian Health Service?" $94.1 \%$ of respondents report that they have any kind of health care coverage.

\subsubsection{The Socio-demographic Variables}

In the demographics module of the BRFSS questionnaire, there are eight mutually exclusive categories of current employment status: employed for wages, self-employed, out of work for more than 1 year, out of work for less than 1 year, a homemaker, a student, retired, and unable to work. This study keeps employed for wages, self-employed, and retired and excludes the rest of the categories (Neuman, 2008; Godard, 2016; Hessel, 2016). A dichotomous indicator is defined for the retirement status if respondents report being retired and for working is defined if respondents report currently as employed or self-employed. $44.80 \%$ and $46.80 \%$ of male and female respondents respectively are retired. The proportion of retirees for widowed respondents is relatively high: $65.80 \%$ of men and $64.20 \%$ of women (Table 2 ).

The study (Hessel, 2016) on the impact of lifestyle risk factors on health outcomes suggested that the level of educational attainment was positively associated with self-rated health, chronic condition, and activity limitation. In this study, the level of education is categorized as less than high school graduation, high school graduation, attended some college or technical school, and four-year college graduation or more. $8.1 \%$ of respondents complete less than high school, and $27.3 \%, 29.1 \%$, and $35.5 \%$ of respondents complete high school graduation, attended some college, and four-year college graduation or more respectively (Table 1). High-income individuals might be likely to exhibit a higher level of demand for commodities of medical and 
health services than low-income individuals since medical and health services in economics are, in general, assumed to be normal goods. The higher level of consumption of medical and health services may be positively associated with improvement in HRQOL. The BRFSS asks participants for the level of their annual household income from all sources. The participants could report one of the eight categories of income levels from less than $\$ 10,000$ to $\$ 75,000$ or more. This study re-categorizes them into five income levels. $11.3 \%$ of participants report an annual household income of less than $\$ 20,000$, and $19.7 \%, 16.8 \%, 19.0 \%$, and $33.2 \%$ of participants report $\$ 20,000 \leq$ income $<\$ 35,000, \$ 35,000 \leq$ income $<\$ 50,000, \$ 50,000 \leq$ income $<\$ 75,000$, and $\$ 75,000$ and over respectively. Studies (Montgomery, et al., 2013; Simms, et al., 2013) investigated race-based health outcomes in adulthood. The studies found that White, non-Hispanic had less likelihood of having physically and mentally unhealthy days than other races. In the demographical questionnaire module, survey participants are also asked for race/ethnicity. This study uses four categories of race/ethnicity variables: White, but not Hispanic; Black, but not Hispanic; Hispanic; and other races. $78.6 \%$ of the respondents are White, non-Hispanic, $8.7 \%$ of respondents are Black, $7.3 \%$ of respondents are Hispanic, and $5.4 \%$ of respondents are other races.

\subsubsection{The Health Behavioral Variables}

It is well known that health behaviors exert a strong influence on health. The present study utilizes three health behavioral variables in the empirical models. First, exercise is defined as a respondent who participates in any physical activities or exercise other than her or his jobrelated regular activities during the past month, including running, calisthenics, golf, gardening, or walking for exercise. $76.0 \%$ of survey respondents report participating in any physical activities or exercises during the past month. Second, a current smoker is defined as a respondent who smokes cigarettes every day or some days. $13.3 \%$ of respondents report as current smokers. Third, a current drinker is defined as a respondent who has at least one drink of alcohol in the past 30 days. One drink is equivalent to a 12-ounce beer, a 5-ounce glass of wine, or a drink with one shot of liquor. $54.0 \%$ of respondents report as current drinkers.

\subsubsection{Chronic health condition}

The study (Horner, et al., 2016) reported that prevalence of the chronic health problems among the retirement-aged population was relatively high as well as the fact that these health problems greatly may affect the quality of life rather than affect mortality outcomes because they were not causes of death. The BRFSS collects data on several chronic health conditions, but only the five chronic health conditions had consistently been in the core components in the BRFSS questionnaire from 2005 to 2016. The participants are asked about chronic health conditions: "Has a doctor, nurse, or other health professional ever told you that you had any of the following?" A heart attack is obtained from the question: "Ever told you had a heart attack, also called a myocardial infarction?"; angina or coronary heart disease is obtained from the questions: "Ever told you had angina or coronary heart disease?"; a stroke is obtained from the question: "Ever told you had a stroke?"; asthma is obtained from the question: "Ever told you have asthma?"; and diabetes is obtained from the question: "Ever told you have diabetes?" $6.9 \%, 7.7 \%, 3.7 \%, 11.0 \%$, and $16.8 \%$ of respondents report having heart attack, angina or coronary heart disease, stroke, asthma, and diabetes respectively (Table 1). 
Figure 1: Proportion of retirement for retirement-aged adults

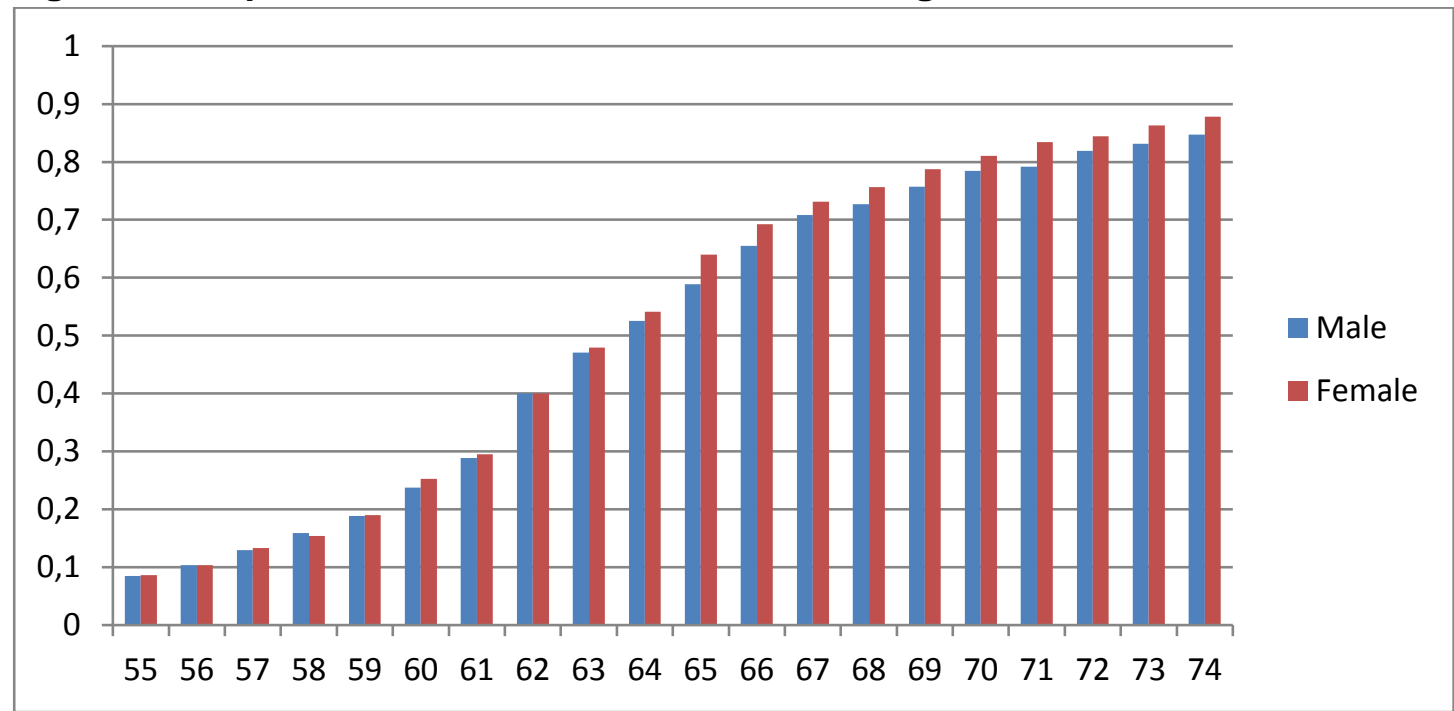

Source: Own calculations based on the 2005-2016 BRFSS data

Table 2: Changes in retirement probability by age

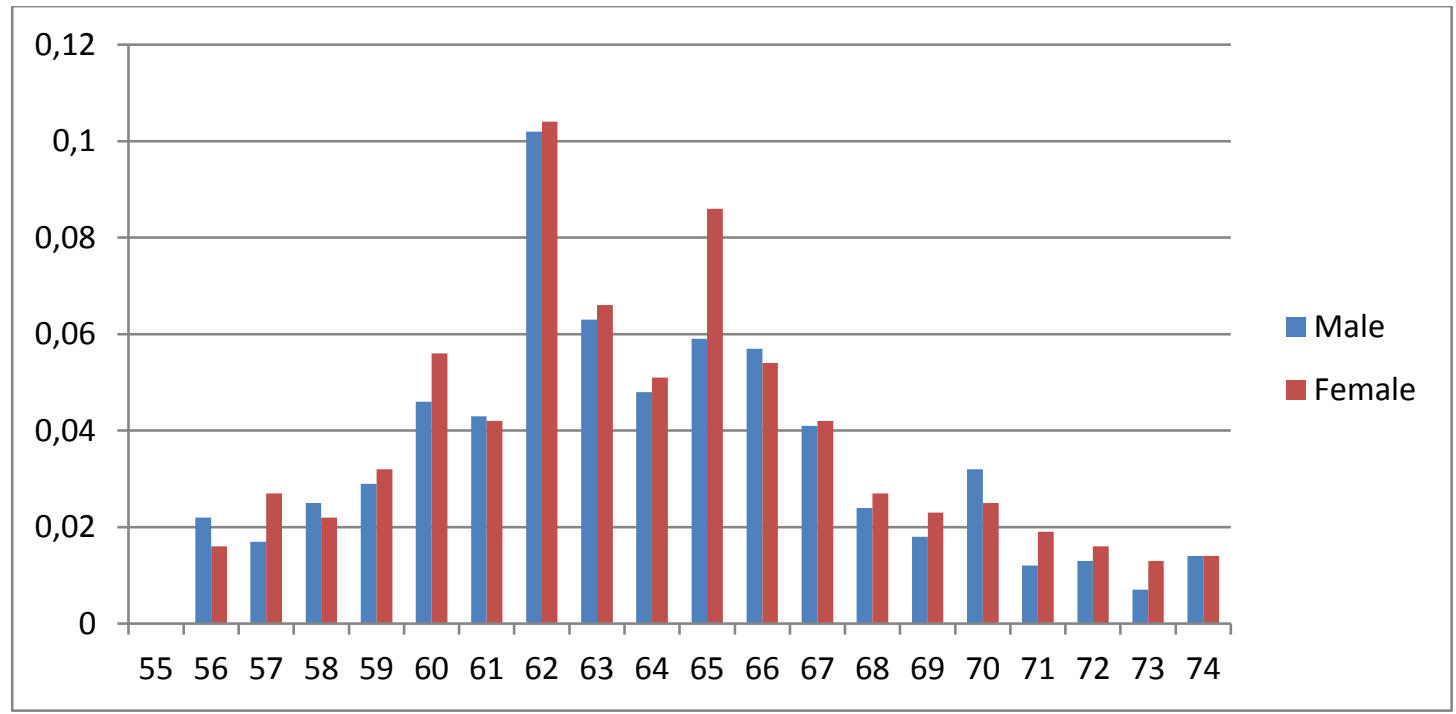

Source: Own calculations based on the 2005-2016 BRFSS data

\section{Analysis and results}

\subsection{Descriptive Analysis}

The descriptive statistics by gender and marital status are calculated with the BRFSS sampling weighting factor (Table 2). Respondents who report being divorced or widowed have a higher average of physically unhealthy days during the past 30 days compared with the respondents who report being married. This implies that divorced or widowed retirement-aged adults are at greater risk for physical health problems compared with married retirement-aged adults. In the education category, respondents who are married or never married have relatively high levels of 
education compared with respondents who are divorced or widowed. 43.2 percent of married men report their annual household income more than $\$ 75,000$, and 39 percent of married women report their household income above $\$ 75,000$. In contrast, the highest percentage among the other marital status subgroups is only $18.4 \%$ for divorced male respondents report their annual income above $\$ 75,000$. It suggests that substantial income disparity exists between married older adults and older adults who are in other types of marital status. The proportion of White respondents who are married is higher than the proportion of White respondents who report being in other types of marital status. For chronic health conditions, the gender difference in the prevalence of chronic health conditions is significant. The percentage of heart attack experiences or coronary heart disease experiences is more than twice higher in males than in females. On the other hand, the prevalence of asthma among female respondents is higher than among male respondents.

\subsection{Retirement Behavior and First Stage Regression Results}

This study investigates whether the early retirement age and full retirement age are critical components in retirement decisions for retirement-aged adults. First, Figure 1 shows that the accumulative proportion of retirees for older adults gradually increases as age rises, but a significant increase in the proportion of retirees at age 62. The figure also shows another considerable increase in the proportion of retirees at age 66. Second, the result of changes in the retirement probability from the probability model (Bonsang, et al., 2012), equation (5), is shown in Figure 2. As expected, the empirical result indicates that the probability of retiring at age 62 is the highest. The figure also shows that probabilities of retiring at ages 65 and 66 at which full social security benefits can be claimed are relatively high. In addition, women start to exit from working much earlier than men before reaching the full retirement age (Figure 1), and Figure 2 shows that the probability of retiring at 60 for women is about $6 \%$ that is significantly higher than the probability of retiring at age 59.

The first-stage regression is about whether the eligible ages for the early and full social security benefits are strong predictors of the retirement decision. The regression results as shown in Table 3 indicate that the instrument variables are statistically significant at the 1 percent level of significance in a two-tailed t-test. The coefficients are estimated by the probability model, equation (3). The probabilities of retiring at reaching the ERA are $12.7 \%$ for men and $13.1 \%$ for women. These results indicate that the ERA is a key predictor of an individual's retirement decision and that the early and full retirement ages as instruments are not weak and have sufficient explanatory power. In other words, the instrumental variable method cannot reject the null hypothesis that the instrumental method can fully solve the endogeneity problem. Also, the first-stage F-statistic indicates that the equation (3) is statistically significant at the 99 percent level of confidence. The effect of the early retirement age on retirement decision is greater than the effect of the full retirement age for both males and females. The effect of early retirement age for females is greater than for males: more females make retirement decisions at the early retirement age, and conversely, more males stay longer at labor force. The positive estimated coefficient for the age, as expected, indicates that aging is associated with an increased 
likelihood of retiring, and age is a statistically significant predictor for making the retirement decision.

Table 3: First stage regression results: probability of being retired.

\begin{tabular}{lcccccccccc}
\hline & \multicolumn{2}{c}{ Overall } & \multicolumn{2}{c}{ Married } & \multicolumn{2}{c}{ Divorced } & \multicolumn{2}{c}{ Widowed } & \multicolumn{2}{c}{ Never Married } \\
\hline Instruments & Male & Female & Male & Female & Male & Female & Male & Female & Male & Female \\
\hline Age & 0.089 & 0.095 & 0.078 & 0.104 & 0.097 & 0.023 & 0.167 & 0.138 & 0.104 & 0.092 \\
& $(29.916)$ & $(35.961)$ & $(22.278)$ & $(28.989)$ & $(13.180)$ & $(4.192)$ & $(11.159)$ & $(17.740)$ & $(9.020)$ & $(8.934)$ \\
Age Squared & -0.000 & -0.000 & -0.000 & -0.000 & -0.000 & 0.000 & -0.001 & -0.000 & -0.000 & -0.000 \\
& $(-21.396)$ & $(-25.311)$ & $(-14.899)$ & $(-20.464)$ & $(-10.088)$ & $(0.418)$ & $(-9.893)$ & $(-14.628)$ & $(-6.703)$ & $(-6.020)$ \\
Early Ret. & 0.127 & 0.131 & 0.118 & 0.140 & 0.157 & 0.115 & 0.120 & 0.104 & 0.134 & 0.106 \\
age & $(54.212)$ & $(62.389)$ & $(42.953)$ & $(51.336)$ & $(27.623)$ & $(26.718)$ & $(9.753)$ & $(16.551)$ & $(15.446)$ & $(13.568)$ \\
Full Ret. age & 0.085 & 0.094 & 0.092 & 0.091 & 0.056 & 0.113 & 0.050 & 0.064 & 0.082 & 0.094 \\
& $(39.366)$ & $(48.423)$ & $(36.420)$ & $(33.588)$ & $(10.454)$ & $(28.146)$ & $(5.754)$ & $(14.433)$ & $(9.106)$ & $(11.576)$
\end{tabular}

\begin{tabular}{lccccccccccc} 
State dummy & yes & yes & yes & yes & yes & yes & yes & yes & yes & yes \\
Year dummy & yes & yes & yes & yes & yes & yes & yes & yes & yes & yes \\
R-square & 0.338 & 0.332 & 0.331 & 0.337 & 0.359 & 0.357 & 0.286 & 0.259 & 0.321 & 0.334 \\
F-state. & 3537.467 & 4364.606 & 2462.764 & 2383.388 & 161.090 & 1045.217 & 160.989 & 572.534 & 218.765 & 277.671 \\
Observations & 582,445 & 736,259 & 417,297 & 394,046 & 92,474 & 158,261 & 33,805 & 137,412 & 38,869 & 46,540 \\
\hline
\end{tabular}

Notes:The t-statistics are in parentheses. All estimated coefficients are statistically significant at 95 percent level of confidence. State and year coefficients are not shown.

Source: Own calculations based on the 2005-2016 BRFSS data.

\subsection{Second Stage Regression Results}

The second stage regression results (Tables 4 and 5) are estimated based on Equation (4) which estimates the potential impact of retirement on the physical and mental health of a one-off change from employment to retirement. This section views retirement as a cumulative process of exposure to being out of the labor force.

\subsubsection{Physically Unhealthy Days}

The second stage regression results for the number of physically unhealthy days (Table 4) suggest that retirement-aged adults who are retired are likely to have more physically unhealthy days than the counterpart of those who are employed. It implies that retirement is negatively associated with physical health outcomes if everything else is held constant. The estimated coefficients of retirement status for women are greater than the coefficient of retirement status for men not only the overall population but across the marital status subgroups except the divorced subgroup. All of the coefficients are also statistically significant at the 95 percent level of confidence in a two-tailed t-test except the coefficients for the divorced subgroup. Among widowed or never married female respondents, retired respondents have 2.208 and 2.203 more physically unhealthy days per month than employed respondents. All of the estimated coefficients of retirement for men are still positive, but mostly they are statistically insignificant. In summary, retirement is negatively associated with the physical health outcome for both men and women, but the association between retirement and the physical health outcome varies by the marital status.

The participants with high school completion or higher are less likely to have physically unhealthy days than the participants who do not complete high school. It induces that individuals with a higher level of education are more efficient producers of physical health if the 
Table 4: Second stage regression results of physical health outcomes ${ }^{a}$

\begin{tabular}{|c|c|c|c|c|c|c|c|c|c|c|}
\hline & \multicolumn{2}{|c|}{ Overall } & \multicolumn{2}{|c|}{ Married } & \multicolumn{2}{|c|}{ Divorced } & \multicolumn{2}{|c|}{ Widowed } & \multicolumn{2}{|c|}{ Never Married } \\
\hline & Male & Female & Male & Female & Male & Female & Male & Female & Male & Female \\
\hline Retired & $\begin{array}{l}0.208 \\
0.731 \mathrm{~b}\end{array}$ & 0.975 & -0.263 & 0.747 & 2.028 & 0.567 & 0.929 & 2.208 & $\begin{array}{l}0.925 \\
0.055 b\end{array}$ & 2.203 \\
\hline Age & $\begin{array}{c}0.024 \\
(0.373)^{b}\end{array}$ & $\begin{array}{c}(4.0 .301 \\
-0.301 \\
(-5.363)\end{array}$ & $\begin{array}{c}(-0.010) \\
0.029 \\
(0.427)^{b}\end{array}$ & $\begin{array}{c}(2.0 .35) \\
-0.351 \\
(-5.033)\end{array}$ & $\begin{array}{l}-0.139 \\
(-0.742)^{b}\end{array}$ & $\begin{array}{c}-0.075 \\
(-0.747)^{b}\end{array}$ & $\begin{array}{c}0.450) \\
-0.259 \\
(-0.427)^{b}\end{array}$ & $\begin{array}{c}(.214) \\
-0.809 \\
(-3.110)\end{array}$ & $\begin{array}{c}0.0 .004 \\
(-0.015)^{b}\end{array}$ & $\begin{array}{c}-0.264 \\
(-1.252)^{b}\end{array}$ \\
\hline Age Squared & $\begin{array}{c}0.000 \\
(-0.336)^{b}\end{array}$ & $\begin{array}{c}0.002 \\
(5.816)\end{array}$ & $\begin{array}{c}-0.000 \\
(-0.022)^{b}\end{array}$ & $\begin{array}{c}0.003 \\
(5.872)\end{array}$ & $\begin{array}{c}0.000 \\
(0.354)^{b}\end{array}$ & $\begin{array}{c}0.000 \\
(0.637)^{b}\end{array}$ & $\begin{array}{c}0.002 \\
(0.430)^{\mathrm{b}}\end{array}$ & $\begin{array}{c}0.006 \\
(3.356)\end{array}$ & $\begin{array}{c}-0.000 \\
(-0.030)^{b}\end{array}$ & $\begin{array}{c}0.001 \\
(0.951)^{b}\end{array}$ \\
\hline Health care & $\begin{array}{c}0.726 \\
(12.554)\end{array}$ & $\begin{array}{c}0.275 \\
(5.710)\end{array}$ & $\begin{array}{c}0.687 \\
(9.800)\end{array}$ & $\begin{array}{c}0.083 \\
(1.285)^{b}\end{array}$ & $\begin{array}{c}0.678 \\
(4.784)\end{array}$ & $\begin{array}{c}0.508 \\
(4.764)\end{array}$ & $\begin{array}{c}0.235 \\
(0.691)^{\mathrm{b}}\end{array}$ & $\begin{array}{c}0.389 \\
(3.013)\end{array}$ & $\begin{array}{c}0.707 \\
(3.630)\end{array}$ & $\begin{array}{c}0.483 \\
(2.204)\end{array}$ \\
\hline Less HS & --- & --- & --- & --- & --- & --- & --- & --. & --- & --. \\
\hline $\mathrm{HS}$ & $\begin{array}{c}-0.502 \\
(-10.440)\end{array}$ & $\begin{array}{c}-0.825 \\
(-18.478)\end{array}$ & $\begin{array}{c}-0.454 \\
(-7.730)\end{array}$ & $\begin{array}{c}-0.952 \\
(-14.418)\end{array}$ & $\begin{array}{c}-0.708 \\
(-6.066)\end{array}$ & $\begin{array}{l}-0.916 \\
(-8.968)\end{array}$ & $\begin{array}{c}-0.371 \\
(-2.122)\end{array}$ & $\begin{array}{c}-0.794 \\
(-9.231)\end{array}$ & $\begin{array}{l}-0.540 \\
(-2.711)\end{array}$ & $\begin{array}{c}-0.469 \\
(-2.168)\end{array}$ \\
\hline Some College & $\begin{array}{c}-0.293 \\
(-5.890)\end{array}$ & $\begin{array}{c}-0.484 \\
(-10.618)\end{array}$ & $\begin{array}{c}-0.298 \\
(-4.907)\end{array}$ & $\begin{array}{c}-0.699 \\
(-10.404)\end{array}$ & $\begin{array}{c}-0.364 \\
(-3.045)\end{array}$ & $\begin{array}{c}-0.552 \\
(-5.345)\end{array}$ & $\begin{array}{c}-0.042 \\
(-0.215)^{b}\end{array}$ & $\begin{array}{c}-0.393 \\
(-4.349)\end{array}$ & $\begin{array}{c}-0.320 \\
(-1.578)^{b}\end{array}$ & $\begin{array}{c}0.003 \\
(0.012)^{b}\end{array}$ \\
\hline College Grad. & $\begin{array}{c}-0.473 \\
(-9.518)\end{array}$ & $\begin{array}{c}-0.602 \\
(-12.842)\end{array}$ & $\begin{array}{c}-0.509 \\
(-8.406)\end{array}$ & $\begin{array}{c}-0.871 \\
(-12.671)\end{array}$ & $\begin{array}{c}-0.476 \\
(-3.895)\end{array}$ & $\begin{array}{c}-0.514 \\
(-4.582)\end{array}$ & $\begin{array}{c}0.010 \\
(0.047)^{b}\end{array}$ & $\begin{array}{c}-0.508 \\
(-4.806)\end{array}$ & $\begin{array}{c}-0.523 \\
(-2.602)\end{array}$ & $\begin{array}{c}-0.217 \\
(-0.921)^{b}\end{array}$ \\
\hline Income \$20 & --- & --- & --. & --- & --- & --- & --- & --- & --- & --- \\
\hline Income \$2 & $\begin{array}{c}-1.645 \\
(-36.118)\end{array}$ & $\begin{array}{c}-1.401 \\
(-40.464)\end{array}$ & $\begin{array}{c}-1.347 \\
(-21.622)\end{array}$ & $\begin{array}{c}-0.965 \\
(-16.909)\end{array}$ & $\begin{array}{c}-1.782 \\
(-16.599)\end{array}$ & $\begin{array}{c}-1.772 \\
(-18.259)\end{array}$ & $\begin{array}{c}-1.787 \\
(-8.239)\end{array}$ & $\begin{array}{c}-1.163 \\
(-10.625)\end{array}$ & $\begin{array}{c}-1.277 \\
(-8.638)\end{array}$ & $\begin{array}{c}-1.442 \\
(-11.231)\end{array}$ \\
\hline Income $\$ 35-50$ & $\begin{array}{c}-2.388 \\
(-42.524)\end{array}$ & $\begin{array}{c}-1.927 \\
(-47.656)\end{array}$ & $\begin{array}{c}-2.112 \\
(-30.705)\end{array}$ & $\begin{array}{c}-1.423 \\
(-24.024)\end{array}$ & $\begin{array}{c}-2.417 \\
(-15.134)\end{array}$ & $\begin{array}{c}-2.512 \\
(-18.259)\end{array}$ & $\begin{array}{c}-2.562 \\
(-7.701)\end{array}$ & $\begin{array}{c}-1.644 \\
(-10.464)\end{array}$ & $\begin{array}{c}-1.737 \\
(-8.921)\end{array}$ & $\begin{array}{c}-2.016 \\
(-12.760)\end{array}$ \\
\hline Income $\$ 50-75$ & $\begin{array}{c}-2.612 \\
(-38.903)\end{array}$ & $\begin{array}{c}-2.091 \\
(-45.991)\end{array}$ & $\begin{array}{c}-2.356 \\
(-30.549)\end{array}$ & $\begin{array}{c}-1.611 \\
(-26.355)\end{array}$ & $\begin{array}{c}-2.558 \\
(-11.748)\end{array}$ & $\begin{array}{c}-2.710 \\
(-15.766)\end{array}$ & $\begin{array}{c}-2.582 \\
(-5.715)\end{array}$ & $\begin{array}{c}-1.709 \\
(-7.887)\end{array}$ & $\begin{array}{c}-1.859 \\
(-7.504)\end{array}$ & $\begin{array}{l}-2.116 \\
(-9.336)\end{array}$ \\
\hline Income $\$ 75+$ & $\begin{array}{c}-2.924 \\
(-30.671)\end{array}$ & $\begin{array}{c}-2.203 \\
(-43.565)\end{array}$ & $\begin{array}{c}-2.731 \\
(-25.619)\end{array}$ & $\begin{array}{c}-1.734 \\
(-25.876)\end{array}$ & $\begin{array}{c}-2.625 \\
(-8.984)\end{array}$ & $\begin{array}{c}-2.879 \\
(-14.210)\end{array}$ & $\begin{array}{c}-2.938 \\
(-3.981)\end{array}$ & $\begin{array}{l}-1.515 \\
(-5.920)\end{array}$ & $\begin{array}{c}-1.893 \\
(-5.595)\end{array}$ & $\begin{array}{c}-2.193 \\
(-6.766)\end{array}$ \\
\hline White & --- & --- & --- & --- & --- & --- & --- & --- & --- & --- \\
\hline Black & $\begin{array}{c}-0.289 \\
(-6.047)\end{array}$ & $\begin{array}{c}-0.562 \\
(-15.338)\end{array}$ & $\begin{array}{c}-0.193 \\
(-3.159)\end{array}$ & $\begin{array}{c}-0.592 \\
(-10.143)\end{array}$ & $\begin{array}{c}-0.544 \\
(-4.981)\end{array}$ & $\begin{array}{c}-0.702 \\
(-8.490)\end{array}$ & $\begin{array}{c}-0.467 \\
(-2.436)\end{array}$ & $\begin{array}{c}-0.500 \\
(-5.496)\end{array}$ & $\begin{array}{c}-0.249 \\
(-1.595)^{b}\end{array}$ & $\begin{array}{c}-0.350 \\
(-3.108)\end{array}$ \\
\hline Hispanic & $\begin{array}{c}-0.029 \\
(-0.484)^{b}\end{array}$ & $\begin{array}{c}0.161 \\
(3.026)\end{array}$ & $\begin{array}{c}0.010 \\
(0.140)^{b}\end{array}$ & $\begin{array}{c}0.256 \\
(3.635)\end{array}$ & $\begin{array}{c}-0.041 \\
(-0.273)^{\mathrm{b}}\end{array}$ & $\begin{array}{c}0.143 \\
(1.264)^{b}\end{array}$ & $\begin{array}{c}-0.551 \\
(-1.882)^{b}\end{array}$ & $\begin{array}{c}-0.078 \\
(-0.574)^{b}\end{array}$ & $\begin{array}{c}0.195 \\
(0.794)^{\mathrm{b}}\end{array}$ & $\begin{array}{c}0.302 \\
(1.390)^{b}\end{array}$ \\
\hline Other race & $\begin{array}{c}0.222 \\
(4.430)\end{array}$ & $\begin{array}{c}0.105 \\
(2.150)\end{array}$ & $\begin{array}{c}0.202 \\
(3.469)\end{array}$ & $\begin{array}{c}0.111 \\
(1.724)^{b}\end{array}$ & $\begin{array}{c}0.246 \\
(1.890)^{\mathrm{b}}\end{array}$ & $\begin{array}{c}0.129 \\
(1.223)^{b}\end{array}$ & $\begin{array}{c}0.599 \\
(2.587)\end{array}$ & $\begin{array}{c}0.263 \\
(2.138)\end{array}$ & $\begin{array}{c}-0.127 \\
(-0.636)^{b}\end{array}$ & $\begin{array}{r}-0.269 \\
(-1.401)^{b}\end{array}$ \\
\hline Exercise & $\begin{array}{c}-2.515 \\
(-77.189)\end{array}$ & $\begin{array}{c}-2.989 \\
(-123.829)\end{array}$ & $\begin{array}{c}-2.322 \\
(-58.777)\end{array}$ & $\begin{array}{c}-2.789 \\
(-86.769)\end{array}$ & $\begin{array}{c}-2.993 \\
(-40.633)\end{array}$ & $\begin{array}{c}-3.082 \\
(-53.348)\end{array}$ & $\begin{array}{c}-3.112 \\
(-18.905)\end{array}$ & $\begin{array}{c}-3.341 \\
(-50.677)\end{array}$ & $\begin{array}{c}-2.434 \\
(-20.960)\end{array}$ & $\begin{array}{c}-3.022 \\
(-33.271)\end{array}$ \\
\hline Current smoker & $\begin{array}{c}0.574 \\
(19.194)\end{array}$ & $\begin{array}{c}0.268 \\
(9.903)\end{array}$ & $\begin{array}{c}0.494 \\
(13.288)\end{array}$ & $\begin{array}{c}0.309 \\
(7.854)\end{array}$ & $\begin{array}{c}0.443 \\
(6.394)\end{array}$ & $\begin{array}{c}0.251 \\
(4.616)\end{array}$ & $\begin{array}{c}0.846 \\
(6.786)\end{array}$ & $\begin{array}{c}0.196 \\
(3.119)\end{array}$ & $\begin{array}{c}0.721 \\
(6.504)\end{array}$ & $\begin{array}{c}0.126 \\
(1.124)^{b}\end{array}$ \\
\hline Current drinker & $\begin{array}{c}-0.787 \\
(-36.983)\end{array}$ & $\begin{array}{c}-0.789 \\
(-41.192)\end{array}$ & $\begin{array}{c}-0.765 \\
(-31.209)\end{array}$ & $\begin{array}{c}-0.712 \\
(-29.210)\end{array}$ & $\begin{array}{c}-0.918 \\
(-15.627)\end{array}$ & $\begin{array}{c}-0.921 \\
(-20.733)\end{array}$ & $\begin{array}{c}-0.994 \\
(-9.978)\end{array}$ & $\begin{array}{c}-0.902 \\
(-18.040)\end{array}$ & $\begin{array}{c}-0.616 \\
(-7.437)\end{array}$ & $\begin{array}{c}-0.724 \\
(-9.240)\end{array}$ \\
\hline CVD HA & $\begin{array}{c}1.381 \\
(35.443)\end{array}$ & $\begin{array}{c}1.686 \\
(33.651)\end{array}$ & $\begin{array}{c}1.345 \\
(30.304)\end{array}$ & $\begin{array}{c}1.580 \\
(22.274)\end{array}$ & $\begin{array}{c}1.326 \\
(12.342)\end{array}$ & $\begin{array}{c}1.602 \\
(14.385)\end{array}$ & $\begin{array}{c}1.730 \\
(10.584)\end{array}$ & $\begin{array}{c}1.795 \\
(16.900)\end{array}$ & $\begin{array}{c}0.997 \\
(5.622)\end{array}$ & $\begin{array}{l}1.904 \\
(8.453)\end{array}$ \\
\hline CVD CHD & $\begin{array}{c}1.952 \\
(50.263)\end{array}$ & $\begin{array}{c}2.809 \\
(61.176)\end{array}$ & $\begin{array}{c}1.804 \\
(41.408)\end{array}$ & $\begin{array}{c}2.516 \\
(40.156)\end{array}$ & $\begin{array}{c}2.366 \\
(21.316)\end{array}$ & $\begin{array}{c}3.234 \\
(31.186)\end{array}$ & $\begin{array}{c}2.324 \\
(13.692)\end{array}$ & $\begin{array}{c}2.925 \\
(28.831)\end{array}$ & $\begin{array}{c}2.329 \\
(13.210)\end{array}$ & $\begin{array}{c}2.534 \\
(12.031)\end{array}$ \\
\hline CVD stroke & $\begin{array}{c}2.737 \\
(50.037)\end{array}$ & $\begin{array}{c}2.704 \\
(52.258)\end{array}$ & $\begin{array}{c}2.726 \\
(42.281)\end{array}$ & $\begin{array}{c}2.656 \\
(36.648)\end{array}$ & $\begin{array}{c}2.653 \\
(19.334)\end{array}$ & $\begin{array}{c}2.661 \\
(23.075)\end{array}$ & $\begin{array}{c}2.675 \\
(11.876)\end{array}$ & $\begin{array}{c}2.640 \\
(22.605)\end{array}$ & $\begin{array}{l}2.304 \\
(9.795)\end{array}$ & $\begin{array}{c}3.046 \\
(13.189)\end{array}$ \\
\hline Asthma & $\begin{array}{c}1.850 \\
(53.030)\end{array}$ & $\begin{array}{c}2.190 \\
(82.816)\end{array}$ & $\begin{array}{c}1.660 \\
(41.918)\end{array}$ & $\begin{array}{c}1.935 \\
(56.601)\end{array}$ & $\begin{array}{c}2.200 \\
(23.015)\end{array}$ & $\begin{array}{l}2.305 \\
(38.952)\end{array}$ & $\begin{array}{c}2.760 \\
(16.312)\end{array}$ & $\begin{array}{c}2.647 \\
(36.828)\end{array}$ & $\begin{array}{c}1.971 \\
(14.192)\end{array}$ & $\begin{array}{c}2.180 \\
(20.951)\end{array}$ \\
\hline Diabetes & $\begin{array}{c}1.815 \\
(59.236)\end{array}$ & $\begin{array}{c}1.728 \\
(62.002)\end{array}$ & $\begin{array}{c}1.714 \\
(49.717)\end{array}$ & $\begin{array}{c}1.680 \\
(46.182)\end{array}$ & $\begin{array}{c}2.230 \\
(25.857)\end{array}$ & $\begin{array}{c}1.730 \\
(26.333)\end{array}$ & $\begin{array}{c}1.630 \\
(10.351)\end{array}$ & $\begin{array}{c}1.814 \\
(25.438)\end{array}$ & $\begin{array}{c}1.938 \\
(15.418)\end{array}$ & $\begin{array}{c}1.685 \\
(14.257)\end{array}$ \\
\hline $\begin{array}{l}\text { State dummy } \\
\text { Year dummy }\end{array}$ & $\begin{array}{l}\text { yes } \\
\text { yes }\end{array}$ & $\begin{array}{l}\text { yes } \\
\text { yes }\end{array}$ & $\begin{array}{l}\text { yes } \\
\text { yes }\end{array}$ & $\begin{array}{l}\text { yes } \\
\text { yes }\end{array}$ & $\begin{array}{l}\text { Yes } \\
\text { Yes }\end{array}$ & $\begin{array}{l}\text { yes } \\
\text { yes }\end{array}$ & $\begin{array}{l}\text { Yes } \\
\text { Yes }\end{array}$ & Yes & Yes & Yes \\
\hline $\begin{array}{l}\text { Year dumr } \\
\text { R-square }\end{array}$ & $\begin{array}{c}\text { yes } \\
0.096\end{array}$ & $\begin{array}{c}\text { yes } \\
0.107\end{array}$ & $\begin{array}{c}\text { yes } \\
0.085\end{array}$ & $\begin{array}{c}\text { yes } \\
0.089\end{array}$ & $\begin{array}{l}\text { Yes } \\
0.116\end{array}$ & $\begin{array}{c}\text { yes } \\
0.115\end{array}$ & $\begin{array}{l}\text { Yes } \\
0.120\end{array}$ & $\begin{array}{l}\text { Yes } \\
0.121\end{array}$ & $\begin{array}{l}\text { Yes } \\
0.083\end{array}$ & $\begin{array}{l}\text { Yes } \\
0.101\end{array}$ \\
\hline F-state. & 745.082 & 1063.678 & 465.107 & 464.643 & 146.015 & 246.838 & 55.325 & 227.719 & 42.204 & 63.187 \\
\hline Observations & 582,445 & 736,259 & 417,297 & 394,046 & 92,474 & 158,261 & 33,805 & 137,412 & 38,869 & 46,540 \\
\hline
\end{tabular}

Notes:a. The t-statistics are in parentheses. All estimated coefficients are statistically significant at 95 percent level of confidence except bs.

Source: Own calculations based on the 2005-2016 BRFSS data.

level of input resources of the production of physical health outcomes is the same across different levels of education. As income rises, individuals are less likely to have physically unhealthy days. The income effect on physical health outcomes for men is greater than the effect for women among married or widowed respondents. For the health behavior variables, as expected, physical exercise would significantly contribute to improving physical health for both 
Table 5: Second stage regression results for mental health outcomes ${ }^{a}$

\begin{tabular}{|c|c|c|c|c|c|c|c|c|c|c|}
\hline & \multicolumn{2}{|c|}{ Overall } & \multicolumn{2}{|c|}{ Married } & \multicolumn{2}{|c|}{ Divorced } & \multicolumn{2}{|c|}{ Widowed } & \multicolumn{2}{|c|}{ Never Married } \\
\hline & Male & Female & Male & Female & Male & Female & Male & Female & Male & Female \\
\hline Retired & -0.877 & -0.476 & $\begin{array}{l}-0.748 \\
\end{array}$ & -0.322 & $\begin{array}{l}-1.478 \\
\end{array}$ & -1.129 & -1.375 & -0.794 & 0.309 & -0.910 \\
\hline & $(-4.151)$ & $(-2.254)$ & $(-3.333)$ & $(-1.303)^{b}$ & $(-2.495)$ & (2.263) & $(-0.777)^{\mathrm{b}}$ & $(-0.912)^{b}$ & $(0.363)^{b}$ & $(-0.967)^{b}$ \\
\hline Age & 0.128 & -0.150 & 0.069 & -0.255 & 0.400 & -0.324 & 0.037 & -0.267 & 0.076 & -0.224 \\
\hline & (2.738) & $(-3.065)$ & $(1.481)^{b}$ & $(-4.258)$ & (2.614) & $(-3.541)$ & $(0.070)^{b}$ & $(-1.175)^{b}$ & $(0.390)^{b}$ & $(-1.240)^{b}$ \\
\hline Age Squared & $\begin{array}{c}-0.001 \\
(-3.823)\end{array}$ & $\begin{array}{c}0.001 \\
(1666)^{b}\end{array}$ & $\begin{array}{c}-0.001 \\
(-2314)\end{array}$ & $\begin{array}{c}0.002 \\
(3.834)\end{array}$ & $\begin{array}{c}-0.003 \\
(-3.201)\end{array}$ & $\begin{array}{c}0.002 \\
(2558)\end{array}$ & $\begin{array}{c}-0.001 \\
(-0.256)^{b}\end{array}$ & $\begin{array}{c}0.001 \\
(0.797)^{b}\end{array}$ & $\begin{array}{c}-0.001 \\
(-0.872)^{b}\end{array}$ & $\begin{array}{c}0.001 \\
(0.892)^{\mathrm{b}}\end{array}$ \\
\hline Health care & $\begin{array}{c}-0.017 \\
(-0.400)^{b}\end{array}$ & $\begin{array}{c}-0.268 \\
(-6.361)\end{array}$ & $\begin{array}{c}-0.121 \\
(-2.488)\end{array}$ & $\begin{array}{c}-0.489 \\
(-8.876)\end{array}$ & $\begin{array}{c}0.231 \\
(2.001)\end{array}$ & $\begin{array}{c}0.005 \\
(0.051)^{\mathrm{b}}\end{array}$ & $\begin{array}{c}0.284 \\
(0.961)^{\mathrm{b}}\end{array}$ & $\begin{array}{c}0.042 \\
(0.373)^{\mathrm{b}}\end{array}$ & $\begin{array}{c}0.056 \\
(0.364)^{\mathrm{b}}\end{array}$ & $\begin{array}{c}0.267 \\
(1.949)^{\mathrm{b}}\end{array}$ \\
\hline Less HS & --- & --- & --- & --- & --- & --- & -.- & --- & -.- & --. \\
\hline $\mathrm{HS}$ & $\begin{array}{c}-0.203 \\
(-5.694)\end{array}$ & $\begin{array}{c}-0.405 \\
(-10.387)\end{array}$ & $\begin{array}{c}-0.185 \\
(-4.550)\end{array}$ & $\begin{array}{c}-0.475 \\
(-8.381)\end{array}$ & $\begin{array}{c}-0.230 \\
(-2.422)\end{array}$ & $\begin{array}{c}-0.504 \\
(-5.440)\end{array}$ & $\begin{array}{c}-0.438 \\
(-2.883)\end{array}$ & $\begin{array}{c}-0.472 \\
(-6.276)\end{array}$ & $\begin{array}{c}-0.356 \\
(-2.264)\end{array}$ & $\begin{array}{c}-0.053 \\
(-0.287)^{b}\end{array}$ \\
\hline Some College & $\begin{array}{c}0.047 \\
(1.267)^{b}\end{array}$ & $\begin{array}{c}-0.178 \\
(-4.476)\end{array}$ & $\begin{array}{c}-0.006 \\
(-0.153)^{b}\end{array}$ & $\begin{array}{c}-0.317 \\
(-5.496)\end{array}$ & $\begin{array}{c}0.093 \\
(0.959)^{\mathrm{b}}\end{array}$ & $\begin{array}{c}-0.152 \\
(-1.622)^{b}\end{array}$ & $\begin{array}{c}-0.102 \\
(-0.608)^{b}\end{array}$ & $\begin{array}{c}-0.390 \\
(-4.936)\end{array}$ & $\begin{array}{c}0.041 \\
(0.254)^{\mathrm{b}}\end{array}$ & $\begin{array}{c}0.532 \\
(2.809)\end{array}$ \\
\hline College Grad. & $\begin{array}{c}-0.001 \\
(-0.028)^{b}\end{array}$ & $\begin{array}{c}-0.330 \\
(-8.051)\end{array}$ & $\begin{array}{c}-0.080 \\
(-1.904)^{b}\end{array}$ & $\begin{array}{c}-0.518 \\
(-8.782)^{b}\end{array}$ & $\begin{array}{c}0.138 \\
(1.389)^{b}\end{array}$ & $\begin{array}{c}-0.161 \\
(-1.582)^{b}\end{array}$ & $\begin{array}{c}-0.193 \\
(-1.036)^{b}\end{array}$ & $\begin{array}{c}-0.535 \\
(-5.799)\end{array}$ & $\begin{array}{c}0.028 \\
(0.179)^{\mathrm{b}}\end{array}$ & $\begin{array}{c}0.392 \\
(1.942)^{b}\end{array}$ \\
\hline Income $\$ 20$ & --- & --- & --- & --- & --- & --. & -.- & --- & --- & --- \\
\hline Income \$2 & $\begin{array}{c}-1.029 \\
(-30.248)\end{array}$ & $\begin{array}{c}-0.911 \\
(-30.121)\end{array}$ & $\begin{array}{c}-0.795 \\
(-18.432)\end{array}$ & $\begin{array}{c}-0.665 \\
(-13.575)\end{array}$ & $\begin{array}{c}-1.077 \\
(-12.326)\end{array}$ & $\begin{array}{c}-1.337 \\
(-15.194)\end{array}$ & $\begin{array}{c}-0.779 \\
(-4.133)\end{array}$ & $\begin{array}{c}-0.684 \\
(-7.159)\end{array}$ & $\begin{array}{c}-1.043 \\
(-8.942)\end{array}$ & $\begin{array}{c}-1.234 \\
(-11.191)\end{array}$ \\
\hline Income $\$ 35-50$ & $\begin{array}{c}-1.501 \\
(-36.079)\end{array}$ & $\begin{array}{c}-1.403 \\
(-39.696)\end{array}$ & $\begin{array}{c}-1.208 \\
(-25.352)\end{array}$ & $\begin{array}{c}-1.025 \\
(-20.189)\end{array}$ & $\begin{array}{c}-1.609 \\
(-12,371)\end{array}$ & $\begin{array}{c}-2.048 \\
(-16.993)\end{array}$ & $\begin{array}{c}-1.135 \\
(-3.927)\end{array}$ & $\begin{array}{c}-1.055 \\
(-7.688)\end{array}$ & $\begin{array}{c}-1.275 \\
(-8.307)\end{array}$ & $\begin{array}{c}-1.771 \\
(-13.047)\end{array}$ \\
\hline Income $\$ 50-75$ & $\begin{array}{c}-1.776 \\
(-35.713)\end{array}$ & $\begin{array}{c}-1.676 \\
(-42.186)\end{array}$ & $\begin{array}{c}-1.396 \\
(-26.128)\end{array}$ & $\begin{array}{c}-1.207 \\
(-23.021)\end{array}$ & $\begin{array}{c}-2.043 \\
(-11.526)\end{array}$ & $\begin{array}{c}-2.456 \\
(-15.752)\end{array}$ & $\begin{array}{c}-1.236 \\
(-3.148)\end{array}$ & $\begin{array}{c}-1.274 \\
(-6.731)\end{array}$ & $\begin{array}{c}-1.499 \\
(-7.671)\end{array}$ & $\begin{array}{c}-2.104 \\
(-10.807)\end{array}$ \\
\hline Income $\$ 75+$ & $\begin{array}{c}-2.203 \\
(-31.190)\end{array}$ & $\begin{array}{c}-2.054 \\
(-46.463)\end{array}$ & $\begin{array}{c}-1.729 \\
(-23.427)\end{array}$ & $\begin{array}{c}-1.502 \\
(-26.152)\end{array}$ & $\begin{array}{c}-2.470 \\
(-10.381)\end{array}$ & $\begin{array}{c}-2.751 \\
(-14.967)\end{array}$ & $\begin{array}{c}-1.929 \\
(-3.008)\end{array}$ & $\begin{array}{c}-1.323 \\
(-5.922)\end{array}$ & $\begin{array}{c}-1.746 \\
(-6.754)\end{array}$ & $\begin{array}{c}-2.488 \\
(-8.936)\end{array}$ \\
\hline White & --- & --- & --- & --- & --- & --- & -..- & --- & -.- & -.- \\
\hline Black & $\begin{array}{c}-0.080 \\
(-2.253)\end{array}$ & $\begin{array}{c}-0.697 \\
(-21.750)\end{array}$ & $\begin{array}{c}0.027 \\
(0.649)\end{array}$ & $\begin{array}{c}-0.557 \\
(-11.114)\end{array}$ & $\begin{array}{c}-0.280 \\
(-3.153)\end{array}$ & $\begin{array}{c}-0.844 \\
(-11.247)\end{array}$ & $\begin{array}{c}-0.689 \\
(-4.139)\end{array}$ & $\begin{array}{c}-0.798 \\
(-10.047)\end{array}$ & $\begin{array}{c}-0.094 \\
(-0.768)\end{array}$ & $\begin{array}{c}-0.517 \\
(-5.356)\end{array}$ \\
\hline Hispanic & $\begin{array}{c}-0.001 \\
(-0.018)^{b}\end{array}$ & $\begin{array}{c}-0.231 \\
(-4.962)\end{array}$ & $\begin{array}{c}0.071 \\
(1.511)^{b}\end{array}$ & $\begin{array}{c}-0.051 \\
(-0.838)^{b}\end{array}$ & $\begin{array}{c}-0.029 \\
(-0.240)^{b}\end{array}$ & $\begin{array}{c}-0.488 \\
(-4.759)\end{array}$ & $\begin{array}{c}0.135 \\
(0.532)^{b}\end{array}$ & $\begin{array}{c}-0.356 \\
(-3.002)\end{array}$ & $\begin{array}{c}0.058 \\
(0.297)^{b}\end{array}$ & $\begin{array}{c}-0.205 \\
(-1.097)^{b}\end{array}$ \\
\hline Other race & $\begin{array}{c}0.258 \\
(6.936)\end{array}$ & $\begin{array}{c}0.048 \\
(1.124)^{b}\end{array}$ & $\begin{array}{c}0.206 \\
(5.123)\end{array}$ & $\begin{array}{c}0.016 \\
(0.098)^{b}\end{array}$ & $\begin{array}{c}0.411 \\
(3.872)\end{array}$ & $\begin{array}{c}0.207 \\
(2.160)\end{array}$ & $\begin{array}{c}0.673 \\
(3.346)\end{array}$ & $\begin{array}{c}-0.027 \\
(-0.248)^{b}\end{array}$ & $\begin{array}{c}0.117 \\
(0.745)^{b}\end{array}$ & $\begin{array}{c}-0.035 \\
(-0.215)^{b}\end{array}$ \\
\hline Exercise & $\begin{array}{c}-0.764 \\
(-31.667)\end{array}$ & $\begin{array}{c}-1.313 \\
(-62.215)\end{array}$ & $\begin{array}{c}-0.651 \\
(-23.805)\end{array}$ & $\begin{array}{c}-1.233 \\
(-44.721)\end{array}$ & $\begin{array}{c}-0.989 \\
(-16.489)\end{array}$ & $\begin{array}{c}-1.548 \\
(-32.857)\end{array}$ & $\begin{array}{l}-1.003 \\
(-7.014)\end{array}$ & $\begin{array}{c}-1.279 \\
(-22.214)\end{array}$ & $\begin{array}{c}-1.029 \\
(-11.242)\end{array}$ & $\begin{array}{c}-1.113 \\
(-14.270)\end{array}$ \\
\hline Current smoker & $\begin{array}{c}0.736 \\
(33.199)\end{array}$ & $\begin{array}{c}1.060 \\
(44.849)\end{array}$ & $\begin{array}{c}0.612 \\
(23.803)\end{array}$ & $\begin{array}{c}1.068 \\
(31.678)\end{array}$ & $\begin{array}{c}0.639 \\
(11.327)\end{array}$ & $\begin{array}{c}0.950 \\
(19.261)\end{array}$ & $\begin{array}{c}0.753 \\
(6.956)\end{array}$ & $\begin{array}{c}0.931 \\
(16.989)\end{array}$ & $\begin{array}{c}0.812 \\
(9.291)\end{array}$ & $\begin{array}{c}1.114 \\
(11.601)\end{array}$ \\
\hline Current drinker & $\begin{array}{c}-0.162 \\
(-10.269)\end{array}$ & $\begin{array}{c}0.009 \\
(0.528)\end{array}$ & $\begin{array}{c}-0.182 \\
(-10.729)\end{array}$ & $\begin{array}{c}-0.035 \\
(-1.676)^{b}\end{array}$ & $\begin{array}{c}-0.276 \\
(-5.763)\end{array}$ & $\begin{array}{c}-0.002 \\
(-0.060)^{b}\end{array}$ & $\begin{array}{c}-0.066 \\
(-0.767)^{b}\end{array}$ & $\begin{array}{c}0.063 \\
(1.440)^{b}\end{array}$ & $\begin{array}{c}-0.106 \\
(-1.617)^{b}\end{array}$ & $\begin{array}{c}0.031 \\
(0.460)^{b}\end{array}$ \\
\hline CVD HA & $\begin{array}{c}0.415 \\
(14.379)\end{array}$ & $\begin{array}{c}0.548 \\
(12.510)\end{array}$ & $\begin{array}{c}0.412 \\
(13.384)\end{array}$ & $\begin{array}{c}0.613 \\
(10.081)\end{array}$ & $\begin{array}{c}0.437 \\
(4.993)\end{array}$ & $\begin{array}{c}0.491 \\
(4.858)\end{array}$ & $\begin{array}{c}0.371 \\
(2.612)\end{array}$ & $\begin{array}{c}0.462 \\
(3.977)\end{array}$ & $\begin{array}{c}0.225 \\
(1.606)^{b}\end{array}$ & $\begin{array}{c}0.873 \\
(4.512)\end{array}$ \\
\hline CVD CHD & $\begin{array}{c}0.677 \\
(23.527)\end{array}$ & $\begin{array}{c}1.255 \\
(31.276)\end{array}$ & $\begin{array}{c}0.587 \\
(19.451)\end{array}$ & $\begin{array}{c}1.102 \\
(20.503)\end{array}$ & $\begin{array}{c}1.001 \\
(11.081)\end{array}$ & $\begin{array}{c}1.622 \\
(17.246)\end{array}$ & $\begin{array}{c}0.898 \\
(6.088)\end{array}$ & $\begin{array}{c}1.259 \\
(14.206)\end{array}$ & $\begin{array}{c}0.745 \\
(5.363)\end{array}$ & $\begin{array}{c}1.045 \\
(5.776)\end{array}$ \\
\hline CVD stroke & $\begin{array}{c}1.313 \\
(32.393)\end{array}$ & $\begin{array}{c}1.393 \\
(30.792)\end{array}$ & $\begin{array}{c}1.218 \\
(27.283)\end{array}$ & $\begin{array}{c}1.271 \\
(20.458)\end{array}$ & $\begin{array}{c}1.607 \\
(14.389)\end{array}$ & $\begin{array}{c}1.645 \\
(15.727)\end{array}$ & $\begin{array}{l}1.207 \\
(6.163)\end{array}$ & $\begin{array}{c}1.319 \\
(12.935)\end{array}$ & $\begin{array}{c}1.002 \\
(5.401)\end{array}$ & $\begin{array}{c}1.759 \\
(8.869)\end{array}$ \\
\hline Asthma & $\begin{array}{c}0.824 \\
(31.881)\end{array}$ & $\begin{array}{c}1.038 \\
(44.919)\end{array}$ & $\begin{array}{c}0.644 \\
(23.488)\end{array}$ & $\begin{array}{c}0.911 \\
(31.074)\end{array}$ & $\begin{array}{c}1.197 \\
(15.379)\end{array}$ & $\begin{array}{c}1.204 \\
(22.437)\end{array}$ & $\begin{array}{c}1.499 \\
(10.194)\end{array}$ & $\begin{array}{c}1.112 \\
(17.714)\end{array}$ & $\begin{array}{c}1.096 \\
(10.010)\end{array}$ & $\begin{array}{c}1.088 \\
(12.170)\end{array}$ \\
\hline Diabetes & $\begin{array}{c}0.546 \\
(24.058)\end{array}$ & $\begin{array}{c}0.574 \\
(23.579)\end{array}$ & $\begin{array}{c}0.505 \\
(21.159)\end{array}$ & $\begin{array}{c}0.622 \\
(19.944)\end{array}$ & $\begin{array}{c}0.685 \\
(9.761)\end{array}$ & $\begin{array}{c}0.567 \\
(9.522)\end{array}$ & $\begin{array}{c}0.613 \\
(4.477)\end{array}$ & $\begin{array}{c}0.554 \\
(8.903)\end{array}$ & $\begin{array}{c}0.444 \\
(4.476)\end{array}$ & $\begin{array}{c}0.513 \\
(5.051)\end{array}$ \\
\hline $\begin{array}{l}\text { State dummy } \\
\text { Year dummy }\end{array}$ & $\begin{array}{l}\text { yes } \\
\text { yes }\end{array}$ & $\begin{array}{l}\text { yes } \\
\text { yes }\end{array}$ & $\begin{array}{l}\text { yes } \\
\text { yes }\end{array}$ & $\begin{array}{l}\text { Yes } \\
\text { Yes }\end{array}$ & $\begin{array}{l}\text { yes } \\
\text { yes }\end{array}$ & $\begin{array}{l}\text { yes } \\
\text { yes }\end{array}$ & $\begin{array}{l}\text { Yes } \\
\text { Yes }\end{array}$ & $\begin{array}{l}\text { Yes } \\
\text { Yes }\end{array}$ & $\begin{array}{l}\text { Yes } \\
\text { Yes }\end{array}$ & Yes \\
\hline $\begin{array}{l}\text { Year aummy } \\
\text { R-square }\end{array}$ & 0.035 & 0.041 & 0.027 & $\begin{array}{l}\text { Yes } \\
0.034\end{array}$ & $\begin{array}{c}\text { yes } \\
0.035\end{array}$ & $\begin{array}{l}\text { yes } \\
0.049\end{array}$ & $\begin{array}{l}\text { Yes } \\
0.034\end{array}$ & $\begin{array}{l}\text { Yes } \\
0.037\end{array}$ & 0.033 & $\begin{array}{l}\text { Yes } \\
0.041\end{array}$ \\
\hline F-state. & 251.747 & 382.556 & 141.869 & 166.050 & 40.948 & 98.500 & 14.312 & 64.328 & 15.869 & 23.856 \\
\hline Observations & 582,445 & 736,259 & 417,297 & 394,046 & 92,474 & 158,261 & 33,805 & 137,412 & 38,869 & 46,540 \\
\hline
\end{tabular}

Notes:a. The t-statistics are in parentheses. All estimated coefficients are statistically significant at 95 percent level of confidence except bs.

Source: Own calculations based on the 2005-2016 BRFSS data

men and women across all marital statuses. Especially, among the widowed respondents, respondents who participate in physical activities have 3.112 and 3.341 days per month fewer physically unhealthy days than respondents who do not currently participate in physical activities. Current drinkers have more physically unhealthy days than non-drinkers. All of the estimated coefficients for the chronic health conditions are positive and statistically significant. It 
means that respondents who report having any of the chronic health problems are more likely to have to physically unhealthy days than those who report having no chronic health problems.

\subsubsection{Mentally Unhealthy Days}

The second stage regression results for the number of mentally unhealthy days (Table 5) suggest that retirement is negatively related to the number of mentally unhealthy days. In other words, retirement is positively associated with retirees' mental health if everything else is held constant. The results show that being retired leads in a reduction of mentally unhealthy days by 1.478 and 1.129 per month for divorced men and women respectively where these estimated coefficients are the greatest among all coefficients across the marital statuses. All retired men have fewer mentally unhealthy days during the past 30 days than retired women except married respondents. The effect of retirement on mental health is statistically insignificant for the widowed and never married subgroups. The positive association of retirement with mental health for divorced respondents is the greatest among the marital status subgroups. In summary, the results indicate that retirement is positively associated with mental health outcomes and that retirement influences retirement-aged adults to improve their mental health differently by marital status.

As expected, respondents who have high school graduation or higher are mostly less likely to have mentally unhealthy days than their counterparts, whereas never married respondents and divorced male respondents who have some college education or higher have more mentally unhealthy days than respondents do not have a high school education. In income categories, the number of mentally unhealthy days falls as income level rises. All of the estimated coefficients for income levels are negative and statistically significant at the 95 percent level of confidence in a two-tailed t-test. This result induces that income has a positive effect on mental health outcomes. Divorced respondents have the greatest positive income effect on mental health outcomes. Participation in physical activities is positively associated with mental health outcomes. The magnitude of the positive effect of physical activities on mental health outcomes for women exceeds the magnitude of the effect for men. Chronic health conditions are estimated to be significantly important factors for mental health outcomes. The results indicate that respondents who report having any of the chronic health problems are more likely to have mentally unhealthy days than respondents who report having none of the chronic health problems.

\section{Discussion}

This study conducts a 2SLS regression analysis using cross-sectional and time series data drawn from the BRFSS which is a large-scale national health survey, a collaborative project between the CDC and all of the states in the United States. This study identifies the differences in the effects of retirement on physical/mental health as health-related quality of life (HRQOL) across four marital status subgroups for the retirement-aged population. The results of the first stage regression indicate that age is a key predictor of the retirement decision for retirementaged adults. Importantly, the probabilities of retiring at the early and full retirement ages are 
robust, and the likelihood of retiring at the early retirement age is greater than the likelihood of retiring at the full retirement age for both males and females. The second stage regression results show that retirement has a detrimental effect on physical health. The negative effect may be associated with withdrawals of job-related physical activities. It may also be associated with that new retirees may have less incentive to invest in their physical health to improve productivity at work because their earning is no longer health dependent. Thus, retirement could influence retirees to lower health capital investment that directly affect their physical health stock. On the other hand, the results suggest that retirement has a strong and beneficial association with mental health. A reduction in work-related stress and responsibilities may be linked to the improvement of mental health. It may also contribute to the improvement of mental health that retirees may have more time for leisure-time physical activity although it depends on the retirees' characteristics such as health behavior.

Overall, retirement is negatively associated with physical health, whereas retirement is positively associated with mental health. Among divorced respondents, retired males are likely to have 2.028 more physically unhealthy days per month than employed males, and retired respondents are likely to have 1.478 and 1.129 more mentally unhealthy days per month for males and females respectively than employed respondents. Widowed or never married females who are retired are likely to have more physically unhealthy days than those who are employed. These retired females in the marital subgroups have the worst retirement effect on physical health. Retired men have fewer mentally unhealthy days than retired women except never married respondents. Divorced respondents have the greatest positive effect of retirement on mental health outcomes across the marital subgroups. In the end, this study finds that the effects of retirement on HRQOL as physical/mental health outcomes substantially differ by marital status.

Numerous studies within socioeconomic and demographic research have consistently identified that married people were more likely to report good health than their unmarried counterparts (Waldron, et al., 1997; Price and Joo, 2005; Shin and Kim, 2017; Jhang, 2018). At the same time, there is increasing diversity in marital status in the U.S. since 1950, such as a decrease in married adults and increases in never married and divorced adults (U.S. Census Bureau, 2018), and there is increasing diversity in marital status at older ages as well (Robards, et al., 2012; Bookwala, et al., 2014). In the context of the social changes at older ages, marital status in retirement-aged adults may be crucial in the transitions that have an impact on their health because retirees may experience better or worse adjustment to the transition of retirement from working based on their marital status. Therefore, understanding the relationship between marital status and health at older ages becomes of increasing importance, and the effects of retirement on health outcomes by marital status should be extensively highlighted. An individual's health behavior or characteristics, such as physical exercise, physician visits, and cooking healthy food at home may be important determinants of health outcomes, but retirement, a stressful life event, which is a turning point for an individual's late life for their lifestyles might be a more significant determinant of health outcomes for the elderly. The retirees' health directly impacts the health care spending from governments. This study finds that the effects of retirement on HRQOL are significantly different among the four subgroups of marital status. It is important for policymakers and public health organizations to improve retirees' overall health for a good quality of life and to 
reduce health care and medical expenses throughout retirement. These remarkable findings could contribute to the existing literature on the effect of retirement on HRQOL by providing additional insight into the association of retirement with HRQOL.

This study does have some limitations which have to be pointed out. First, although previous literature has proven the reliability of the measure of HRQOL from the BRFSS and it has been widely used in health research, the self-reported health status may not be subjective by the individual participants. There is no standard measure of health status, and the self-reported health outcomes are just individual participants' self-perceptions of mental/physical health. Second, retired individuals may have different retirement effects on health depending on the duration of their retirement. New retirees may experience relief from the burdens of working life in the initial status of retirement, but after a period of accommodation, the retirees may face negative aspects, such as a poorer social life and idleness, which are causes of negative effects on wellbeing (Halleröd, et al., 2013). The study (Bonsang, et al., 2012) suggested that the effect of changes in lifestyle on cognitive functioning would not be immediately apparent and that it was unlikely that retirement had an instantaneous impact on cognitive functioning. Also, the study (Zhu, 2016) found that the duration of retirement was a significant determinant of physical/mental health. In short, the impact of retirement on health does not appear immediately. The BRFSS data carries out at a single point in time among different groups from each time data are collected, and it does not provide the duration of retirement status. Third, the retirement status from the BRFSS does not provide types of retirement. The effect of retirement on health may differ based on types of retirement (voluntary, involuntary or regulatory). A study (van der Heide, et al., 2013) reported that involuntary retirees, especially with health reasons, were more likely to perceive a decline in perceived general health after retirement than voluntary retirees.

\section{References}

ANDERSON, E. M.; CATLIN, T. K.; WYRWICH, K. W.; and JACKSON-THOMPSON, J. (2003). Retest reliability of surveillance questions on health related quality of life. Journal of Epidemiology and Community Health. Vol. 57, No. 5, 339-343. https://doi.org/10.1136/jech.57.5.339

BONSANG, E.; ADAM, S.; and PERELMAN, S. (2012). Does retirement affect cognitive function? Journal of Health Economics. Vol. 31, No. 3, 490-501. https://doi.org/10.1016/j.jhealeco.2012.03.005

BOOKWALA, J.; MARSHALL, K. I.; and MANNING, S. W. (2014). Who needs a friend? Marital status transitions and physical health outcomes in later life, Health Psychology. Vol. 33, No. 6, 505-515. https://doi.org/10.1037/hea0000049

BROWN, W. J.; TROST, S. G.; BAUMAN, A.; MUNNERY, k.; and OWEN, N. (2004). Test-retest reliability of four physical activity measures used in population surveys. Journal of Science and Medicine in Sport. Vol. 7, No. 2, 205-215. https://doi.org/10.1016/S1440-2440(04)80010-0

CHEN, H. Y.; BAUMGARDNER, D. J.; and RICE, J. P. (2011). Health-related quality of life among adults with multiple chronic conditions in the United States, Behavioral Risk Factor Surveillance System, 2007. Preventing Chronic Disease. Vol. 8, No. 1, 1-9. 
CLIFFORD, E. L.; COLLINS, M. M.; BUCKLEY, C. M.; FITZGERALD, A. P.; and PERRY, I. J. (2013). Unhealthy days and quality of life in Irish patients with diabetes. PLOS ONE. 8(12): e81102. https://doi.org/10.1371/journal.pone.0081102.

CLOUSTON, S. A. P. and DENIER, N. (2017). Mental retirement and health selection: Analyses from the U.S. Health and Retirement Study. Social Science \& Medicine. Vol. 178, 78-86. https://doi.org/10.1016/j.socscimed.2017.01.019

DAVE, D.; RASHAD, I.; and SPASOJEVIC, J. (2008). The effect of retirement on physical and mental health outcomes. Southern Economic Journal. Vol. 75, No. 2, 497-523.

$\mathrm{EIBICH}, \mathrm{P}$. (2015). Understanding the effect of retirement on health: Mechanisms and heterogeneity. Journal of Health Economics. Vol. 43(Sept.), 1-12. https://doi.org/10.1016/j.jhealeco.2015.05.001

EVENSON, K. R. and MCGINN, A. P. (2005). Test-retest reliability of adults surveillance measures for physical activity and inactivity. American Journal of Preventive Medicine. Vol. 28, No. 5, 470-478. https://doi.org/10.1016/j.amepre.2005.02.005

FORD, E. S.; MOKDAD, A. H.; LI, C.; MCGUIRE, L. C.; STRINE, T. W.; OKIRO, C. A.; BROWN, D. W.; and ZACK, M. M. (2008). Gender differences in coronary heart disease and health-related quality of life: findings from 10 states from the 2004 Behavioral Risk Factor Surveillance System. Journal of Women's Health. Vol. 17, No. 5, 757-768. https://doi.org/10.1089/jwh.2007.0468

GANDHI, P. K.; GENTRY, W. M.; KIBETT I.; JEFFERY, L.; LEE, E. Y.; JORDAN, W.; BOTTORFF, M. B.; and HUANG, I. C. (2015). The relationship between four health-related quality-of-life indicators and use of mammography and Pap test screening in US women. Quality of Life Research. Vol. 24, No. 9, 2113-2128. https://doi.org/10.1007/s11136-015-0968-9

GODARD, M. (2016). Gaining weight through retirement? Results from the SHARE survey. Journal of Health Economics. Vol. 45, 27-46. https://doi.org/10.1016/j.jhealeco.2015.11.002

GROSSMAN, M. (1972). On the concept of health capital and the demand for health. The journal of Political Economy. Vol. 80, No. 2, 223-255. https://doi.org/10.1086/259880

HALLERÖD, B.; ÖRESTIG, J.; and STATTIN, M. (2013). Leaving the labour market: the impact of exit routes from employment to retirement on health and wellbeing in old age. European Journal of Aging. Vol. 10, 25-35. https://doi.org/10.1007/s10433-012-0250-8

HEATH, G. W. and BROWN, D. W. (2009). Recommended levels of physical activity and health related quality of life among overweight and obese adults in the United States, 2005. Journal of Physical Activity and Health. Vol. 6, No. 4, 403-411. https://doi.org/10.1123/jpah.6.4.403

HESSEL, P. (2016). Does retirement (really) lead to worse health among European men and women across all educational levels? Social Science \& Medicine. Vol. 151, Issue C, 19-26. https://doi.org/10.1016/j.socscimed.2015.12.018

HORNER, E. M. and CULLEN, M. R. (2016). The impact of retirement on health: quasi-experimental methods using administrative data. BMC Health Services Research. Vol.16:68, 1-9. https://doi.org/10.1186/s12913-016-1318-5.

HORNER-JOHNSON, W.; SUZUKI, R.; KRAHN, G. L.; ANDERSON, E. M.; DRUM, C. E., and the RRTC Expert Panel on Health Measurement. (2010). Structure of health-related quality of life among 
people with and without functional limitations. Quality of Life Research. Vol. 19, No. 7, 977-984. https://doi.org/10.1007/s11136-010-9664-y

JIA, H. and LUBETKIN, E. I. (2009). Time trends and seasonal patterns of health-related quality of life among U.S. adults. Public Health Report. Vol. 124, No. 5, 692-701. https://doi.org/10.1177/003335490912400511

JHANG, F. H. (2018). Changes in marital status and links to self-rate health: A study of temporal relationships. The Social Science Journal. Vol. 55, 87-96. https://doi.org/10.1016/j.soscij.2017.08.001

KAPP, J. M.; JACKSON-THOMPSON, J.; PETROSKI, G. F.; and SCHOOTMAN, M. (2009). Reliability of health-related quality of life indicators in cancer survivors from a population-based sample, 2005, BRFSS. Public Health. Vol. 123, No. 4, 321-325. https://doi.org/10.1016/j.puhe.2008.10.005

KUVAJA-KÖLLNER, V.; VALTONEN, H.; KOMULAINEN, P.; HASSINEN, M.; and RAURAMAA, R. (2013). The impact of time cost of physical exercise on health outcomes by older adults: the DR's EXTRA Study. European Journal of Economics. Vol. 14, No. 3, 471-479. https://doi.org/10.1007/s10198012-0390-y

LATIF, E. (2012). The impact of retirement on health in Canada. Canadian Public Policy - Analyse de Politiques. Vol. 38, No. 1, 15-29. https://doi.org/10.3138/cpp.38.1.15

MAHABALESHWARKAR, R.; KHANNA, R.; WEST-STRUM, D.; and YANG, Y. (2013). Association between health-related quality of life and colorectal cancer screening. Population Health Management. Vol. 16, No. 3, 178-189. https://doi.org/10.1089/pop.2012.0044

MESBAH, M. (2004). Measurement and analysis of health related quality of life and environment data. Environmetrics. Vol. 15, 471-481. https://doi.org/10.1002/env.680

MEYER, O. L.; CASTRO-SCHILO, L.; and AGUILAR-GAXIOLA, S. (2014). Determinants of mental health and self-rated health: A model of socioeconomic status, neighborhood safety, and physical activity. American Journal of Public Health. Vol. 104, No. 9, 1734-1741. https://doi.org/10.2105/AJPH.2014.302003

MONTGOMERY, A. E.; CUTULI, J. J.; EVANS-CHASE, M.; TREGLIA, D.; and CULHANE, D. P. (2013). Relationship among adverse childhood experiences, history of active military service, and adult outcomes: homelessness, mental health, and physical health. American Journal of Public Health. Vol. 103, S. 2, S262-S268. https://doi.org/10.2105/AJPH.2013.301474

MOTEGI, H. NISHIMURA, Y.; and TERADA, K. (2016). Does retirement change lifestyle habits? The Japanese Economic Review. Vol. 67, No. 2, 169-191. https://doi.org/10.1111/jere.12104

National Center for Health Statistics, Centers for Disease Control and Prevention. (2017). https://www.cdc.gov/nchs/data/hus/2017/015.pdf.

NEUMAN, K. (2008). Quit your job and get healthier? The effect of retirement on health. Journal of Labor Research. Vol. 29, 177-201. https://doi.org/10.1007/s12122-007-9036-8

PRICE, C. A. and JOO, E. (2005). Exploring the relationship between marital status and women's retirement satisfaction. International Journal of Aging and Human Development. Vol. 61, No. 1, 3755. https://doi.org/10.2190/TXVY-HAEB-XOPW-00QF 
ROBARDS, J.; EVANDROU, M.; FALKINGHAM, J.; and VLACHANTONI, A. (2012). Marital status, health and mortality. Maturitas. Vol. 73, 295-299. https://doi.org/10.1016/j.maturitas.2012.08.007

SHAI, O. (2018). Is retirement good for men's health? Evidence using a change in the retirement age in Israel. Journal of Health Economics. Vol. 57, 15-30. https://doi.org/10.1016/j.jhealeco.2017.10.008

SHIN, S. and KIM, H. (2017). Marital status, health, and retirement wealth for middle aged and older women. Financial Services Review. Vol. 28, 255-270.

SIMMS, K.; HACKER, D. S.; PARKER, A. J.; FIGUEREO, M. E.; and BOCK, S. (2013). Do past or present adverse relationship experiences have greater impact on mental and physical health? Advances in Mental Health. Vol. 11, No. 2, 122-130.

SON, C. H. (2016). The effect of adverse childhood experiences on self-reported physical and mental health outcomes in adulthood. Journal of Economics and Behavioral Studies. Vol. 8, No. 3, 104-114. https://doi.org/10.22610/jebs.v8i3(J).1292

SON, C. H. (2018). Health-related quality of life in consequences from frequency-quantity measures of alcohol consumption patterns. International Journal of Happiness and Development. Vol. 4, No. 3, 236-260. https://doi.org/10.1504/IJHD.2018.10014875

SON, C. H. and LEE, D. H. (2014). The effects of alcohol consumption patterns on cardiovascular disease: An empirical study with Behavioral Risk Factor Surveillance System data. The Empirical Economics Letters. Vol. 13, No. 7, 723-730.

Unites States Census Bureau. (2018). Historical Marital Status Tables. https://www.census.gov/data/tables/time-series/demo/families/marital.html.

VAN DER HEIDE, I.; VAN RIJN, R. M.; ROBROEK, S. J. W.; BURDORF, A.; and PROPER, K. I. (2013). Is retirement good for your health? A systematic review of longitudinal studies. BMC Public Health. 13:1180. doi:10.1186/1471-2458-13-1180.

VO, K.; FORDER, P. M.; TAVENER, M.; RODGERS, B.; BANKS, E.; BAUMAN, A.; and BYLES, J. E. (2015). Retirement, age, mental health: findings from the 45 and Up Study. Aging \& Mental Health. Vol. 19, No. 7, 647-657. https://doi.org/10.1080/13607863.2014.962002

WALDRON, I.; WEISS, C. C.; and HUGHES, M. E. (1997). Marital status effects on health: are there differences between never married women and divorced and separate women? Social Science \& Medicine. Vol. 45, No. 9, 1387-1397. https://doi.org/10.1016/S0277-9536(97)00065-8

ZHU, R. (2016). Retirement and its consequences for women's health in Australia. Social Science \& Medicine. Vol. 163, 117-125. https://doi.org/10.1016/j.socscimed.2016.04.003

ZULLIG, K. J. and HENDRYX, M. (2010). A comparative analysis of health-related quality of life for residents of U.S. counties with and without coal mining. Public Health Report. Vol. 125, No. 4, 548555. https://doi.org/10.1177/003335491012500410 
